\title{
Epistemology of Textual Re-use in the Nyāyamañjarī
}

\author{
Alessandro Graheli
}

Published online: 25 September 2014

(C) The Author(s) 2014. This article is published with open access at Springerlink.com

\begin{abstract}
The epistemology of śabda is one of the main themes in Bhatta Jayanta's Nyāyamañjarī, and, in the hypotheses explored in this paper, also the conceptual basis of Jayanta's textual re-use. The sixth chapter of the Nyāyamañjari contains a debate between Vaiyākaraṇas and Mīmāṃsakas who, respectively, advocated an holistic or atomistic theory of language. Selected Jayanta's re-uses from Vyākaraṇa, Mīmāṃsā, and Nyāya sources are here surveyed and analyzed, with a focus on their meaning and on the context. The method of analysis is partially following Moravcsik's scheme for a classification of citations, as well as Small's classification by symbolic functions. By re-using texts Jayanta not only imparted authority to his own arguments, but also reassessed the relation of his tradition with other ones. Re-used ideas and words stand for symbols of those authors' tenets, and those authors represent symbols of their respective traditions. Moreover, by quoting a certain author Jayanta often anointed him with a symbolic status of trustworthy authority, and his statement with a status of śabdapramāna.
\end{abstract}

Keywords Jayanta $\cdot$ Nyāyamañjarī $\cdot$ Citations · Textual re-use · Verbal testimony $\cdot$ Śabda

\footnotetext{
This paper is based on the material gathered for the forthcoming critical edition of the sixth chapter of Bhațta Jayanta's Nyāyamañjari, for the large part researched during project M-1160 G-15, July 2009 to June 2011, a project financed by the FWF (Fonds zur Förderung der wissenschaftlichen Forschung) and based at the ISTB, University of Vienna. Manuscript material used in relation to this paper was provided by the NBh projects at the ISTB (FWF Projects P-17244, P-19328 and P-24388). For most of the Nyāyabhäsya quotations used in this paper I am indebted to these projects, and to Karin Preisendanz in particular. Special thanks are due to Elisa Freschi, who read early drafts of the paper and enhanced its value by insightful remarks.
}

\footnotetext{
A. Graheli $(\bowtie)$

Department of South Asian, Tibetan and Buddhist Studies, University of Vienna, Vienna, Austria e-mail: alessandro.graheli@univie.ac.at
} 


\section{Introduction}

\subsection{Bhatta Jayanta and the Nyāyamañjarī (NM)}

The Nyāyamañjarī (henceforth NM) is a treatise on the tenets of Nyāya, the system of epistemology, dialectics and logic traditionally rooted in the Nyāyasütra (NS). It was written by Bhatta Jayanta in the ninth century CE. ${ }^{1}$

The NM is composed of 12 chapters. In NM 3 to 6 , about one third of the whole work, Jayanta examines in depth the epistemology of śabda (on this term, see Sect. 2). The present paper is grounded on a survey of a selection of re-use of texts in the sphota section of NM 6. By "re-use" I mean the adoption of previously existing textual passages and ideas, as a general and widely encompassing term. Verbatim re-use will be here called "quotation", in cases where I am confident that Jayanta is consciously quoting existing texts.

This particular section of the NM consists of an investigation on the aetiology of śabda-produced knowledge, in which Jayanta stages a debate among Vyākarana and Mīmāmssā schools. There are three main reasons behind the choice of this particular section: first, my critical edition of this portion, based on all the available manuscripts, ${ }^{2}$ is at an advanced stage, so its text is for the purposes of this paper more reliable than that of other parts of the NM; secondly, with a well structured sequence of arguments and counter-arguments, such as that of this section of the $\mathrm{NM}$, it is easier to assess the function of textual re-use in Jayanta's system; thirdly, in the course of the editing process, I had already identified a significant amount of re-used passages and their sources, which allows me to invest time and energy in evaluating re-uses, rather than in tracing them.

\subsection{Truth-Values, Epistemic Function, and Symbolic Effect of Re-used Texts}

In the analysis and classification I will mostly focus on the quality and the context of re-uses. Following in part the scheme for a classification of citations devised by Moravcsik and Poovanalingam (1975) and the classification by symbolic functions, introduced by Small (1978), I will classify re-uses in the NM by asking the following questions about Jayanta's intentions:

(1) Truth value: Is the re-use confirmatory or negational? In other words, did Jayanta consider the re-used passage true or false?

(2) Symbolic value: Which tradition, author, or idea does the re-used text stand for?

Moravcsik and Poovanalingam (1975, p. 88) envision four dichotomies in their scheme: (1) conceptual/operational, (2) organic/perfunctory, (3) evolutionary/ juxtapositional, (4) confirmatory/negational. Of these four, (1) is ignored here,

\footnotetext{
1 For evidence about the date and other biographic information on Bhatța Jayanta, also known as Jayanta Bhatța, see Slaje (1986, p. 245 ff.), Potter (1995, pp. 345-346), Dezsô (2005, Introduction), Kataoka (2007), Slaje (2012).

2 For a list and description of extant NM manuscripts, see Graheli (2012a).
} 
since it is specific to the natural sciences. (2) and (3) would both be relevant, but for want of space they will need to be addressed elsewhere. (4) is here discussed and implemented in terms of truth-value.

As for the symbolic function, it was introduced by Small (1978, p. 328):

[Previous] studies have missed the role citations play as symbols of concepts or methods. This cognitive function arises from the formal requirement imposed on the scientist-author of embedding his references to earlier literature in a written text. This leads to the citing of works which embody ideas the author is discussing. The cited documents become, then, in a more general sense, 'symbols' for these ideas.

[...] In the tradition of scholarship, the references are the 'sources' which the author draws upon to give further meaning to his text. Reversing this view, as I am suggesting here, the author is imparting meaning to his 'sources' by citing them.

[...] In general, [by 'symbolic'] I mean that an object 'stands for' an idea; for citations, the cited document is the 'object' and the 'idea' is expressed in the text which cites it.

When applied to the re-use of texts in the NM, the term "symbolic" can encompass at least three different levels, the first two intended by the author, the third probably accidental: ${ }^{3}$

- By re-using texts, Jayanta not only imparted authority to his own arguments, but also reassessed the relation of his tradition with other ones. Re-used ideas and words stand for symbols of those authors' tenets, and those authors represent symbols of their respective traditions.

- By quoting a certain author Jayanta may intend to assign him a symbolic status of trustworthy authority (apta), and to his statement a status of śabdapramāna.

- By arranging textual passages in a new order (see Sect. 4), Jayanta endowed them with new meanings.

While analyzing the context and the structure of re-uses, I will therefore try to identify the tradition, author, and concept symbolized by the cited text.

\subsection{Contents of this Paper}

The epistemology of śabda is not only the subject matter of NM 6, but also, in the hypotheses explored in this paper, the conceptual basis of Jayanta's re-use of sources. Therefore, in Sect. 2 a brief sketch of the epistemology of śabda is provided.

In the sphota section of NM 6 Jayanta hardly ever re-uses material from his own tradition. The reasons behind this absence of Nyāya sources are explored in Sect. 3.

\footnotetext{
3 A concise yet exhaustive survey on the use of the term "symbol" can be found in Eco (1996, pp. 199225). Symbols as "linguistic signs which are conventional and arbitrary" (see pp. 210-211), according to Eco already used by Aristotle in a similar sense, seem particularly relevant in the present application of the NM.
} 
Further clues about Jayanta's attitude in relation to his own tradition can be derived from some introductory verses of the NM. The most relevant passages are examined in Sect. 4.

Section 5 is a synopsis of the structure of sphota section of NM 6, needed to facilitate the comprehension of my analysis of the style and the epistemic value of re-uses. Arguments for and against the sphota theory are staged as an articulate dialog between Vaiyākaraṇas and Mīmāṃsakas. Accordingly, in Sects. 7 and 8, textual re-uses in the whole sphoța section are surveyed in two distinct parts.

For a more exhaustive assessment of Jayanta's modality of re-use, I decided to compare his treatment of Mīmāṃsā and Vyākaraṇa sources with that of Nyāya ones, and since Nyāya sources are almost absent in NM 6, in Sect. 9 some NS and NBh reuses from other parts of the NM are also examined.

\section{The Epistemology of śabda}

In Nyāya an authoritative instance of śabda must come from a source that satisfies the criteria of trustworthiness. If textual re-use has epistemic purposes, therefore, clarity about the identification of the source and its authoritativeness becomes particularly relevant. The formal style of a quotation, moreover, may reflect an appreciation or criticism of the source, in conformity with the assessment of a given quotation as representing an accepted truth or a false tenet. To contextualize the survey of quotations in the NM, some basic notions related to śabda epistemology are discussed next.

\subsection{Comprehension, Knowledge, and Their Object}

In most cases I will leave untranslated the terms śabda and artha, in want of English equivalents that can give justice to their technical and polysemous usages. Also, the two terms are not always treated homogeneously in Nyāya, Mīmāṃsā and Vyākaraṇa. As a general orientation, in the present context śabda is to be understood as "epistemic linguistic expression", i.e., "linguistic expression having the purpose of conveying knowledge", and its artha as "object of epistemic linguistic expression". Although śabda is often rendered with "word" or, at best, "linguistic expression", and artha with "meaning", such equivalents fail to convey the epistemic import of these terms.

In the use of Sanskrit expressions such as śabdabodha, śabdārthapratīti, śabdārthasampratyaya, padārthapratipatti, vākyārthapratipatti, etc., the distinction between understanding words and knowing from words is not explicit and is philosophically problematic. As noted by Matilal and Chakrabarti (1994, Introduction, pp. 9-11), in Nyāya literature the implied assumption is that verbal knowledge (śabdabodha) is "knowledge derived from the words of a truth-teller", rather than "understanding of words", although in English translations a tendency to render śabda and artha in the latter context seems prevalent. 
The conflation of "comprehension of words" and "knowledge from words" that we witness in Sanskrit literature, however, may not necessarily be a philosophical flaw, if we consider how comprehension is a fundamental and inextricable part of word-derived knowledge. ${ }^{4}$

\section{2 Śabda in Nyāya}

In NBh ad 1.1.7, śabda as an instrument of knowledge is defined as follows:

$s ́ a b d a$ is the instruction (upadeśa) of a trustworthy instructor. It is of two kinds, since it can have either a perceivable or an imperceivable artha. āptopadeśah śabdaḥ // sa dvividho drșțādrșțārthatvāt //

The trustworthiness of the source concerns language in general, so that it is considered the ground for the validity of both common and Vedic language. Unlike in Mīmāmsāa, in Nyāya the authority of the Veda is also founded on the trustworthiness of their source:

And that [Veda] is a valid source of knowledge because its trustworthy instructor is a valid source.

\section{[...] tatprāmāṇyam āptaprāmānyāt //}

A trustworthy instructor is defined as follows:

Trustworthy is the instructor (upadestr) who has directly experienced the essential property (dharma) [of things], and is moved by the desire to describe [things] as they are or they are not.

āptaḥ khalu sākșātkrtadharmā yathādrșțasyādrșțasya cikhyāpayiṣayā prayukta upadeștā /

Being grounded on the utterance of a trustworthy instructor, śabda can by no means be considered permanent (nitya) by the Naiyāyikas, since such an utterance must have occurred at some point in time. Moreover, the relation between śabda and artha is considered conventional, rather than natural, because it is based on stipulations (sanketa) established by divine or human beings (NBh ad 2.1.55-56).

\subsection{Differences in Mīmāṃsā and Vyākaraṇa}

In Mīmāṃsā, śabda is accepted ipso facto as natural and unalterable (Mīmāmsāāūtra 1.1.5, see ŚSh, p. 28), so issues related to its development or aetiology are deliberately ignored as pointless. The possibility of an author is irrelevant for its

\footnotetext{
4 The Nyāya and Mīmāmssā traditions are counted by Julie Jack (1994) among exponents of what she labels "Uniqueness School", according to which there is a "uniqueness of knowing from words as a form of knowledge,-its irreducibility either to perception or to inference [...]" (1994, p. 165). In her essay she also explores the problematic overlap of comprehension, judgment, and rational belief in verbal testimony.
} 
validity as an instrument of knowledge (which in Mīmāṃsā is, specifically, knowledge of dharma) and for its reality, i.e. its relation with a (mental or concrete) object. The fixedness (nityat $\bar{a}$ ) of such a relation necessarily implies the permanence of śabda: the idea that śabda is ephemeral, common to most opponents of Mīmāṃsā, is rejected in Mìmāmsāsūtra 1.1.18:

[śabda] must be permanent (nitya) [in relation to its artha], because [its] appearance is for the purpose of [communicating with] someone else.

nityas tu syād darśanasya parārthatvāt //

If śabda were ephemeral, how could there be a continuous and consistent intersubjectivity of speakers and hearers, who comprehend a same expression in the same way? To account for the sheer phenomenon of communication, the relation of a śabda with an artha must be understood as stable and permanent.

In Bhartrhari's philosophy of grammar, the ultimate reality (paramārtha) is a non-dual śabdatattva, while all dualities and differences, including the distinction into śabda and artha, appear as such only on the relative level of worldly interactions (vyavahāra), and not in an absolute, real sense (see VP, 1.1).

Moreover, since the ultimate reality is śabda, true knowledge must be grounded in it (VP, 1.131):

In this world there is no cognition without the comprehension of śabda. Every

knowledge shines as if penetrated by śabda.

na so 'sti pratyayo loke yah śabdānugamād ṛte /

anuviddham iva jñānam sarvam śabdena bhāsate //

Jayanta sums up Bhartṛhari's philosophy of śabda as follows $\left(\mathrm{NM}^{\mathrm{Va}} \mathrm{II}\right.$, pp. 156,19-157,1):

The non-dual Absolute, śabda, whose apparent differences are caused by traces of a beginning-less nescience, is deceptively perceived as if related to the artha. There is actually no signified thing separated from the signifier. Therefore, this signified-signifier (vācyavācaka) subdivision, which is merely theoretical, is nothing but nescience used as a tool to achieve awareness (vidyā).

The non-dual reality is śabda, so in Bhartrihari's perspective Nyāya concepts such as "trustworthy instructor" and "conventional meaning" are fictional ones. Also the śabda-artha dichotomy is imaginary, since such duality does not exist in reality. The segmentation of language into sentences, words, and phonemes is an artificial operation, certainly useful for didactic purposes, but ultimately unreal.

\subsection{The Oral and Written śabda}

Traditionally, in India, śabda typically pertains to the realm of orality, while present analyses of textual re-use mostly concern written literature. ${ }^{5}$ It is debatable to what

\footnotetext{
5 The distinction between the oral and written nature of śabda is not always made, e.g. in Saksena (1951, pp. 38, 46), who interprets śabda as "verbal or written authority" or "verbal or written testimony". Bhattacharyya (1994, p. 76) points to an important difference, relevant to the context of the NM, between spoken and written expressions: "Whether what is spoken endures when speaking is over is debatable;
} 
extent Jayanta used written sources or, rather, had them committed to memory when he wrote the NM.

We also do not know how works such as the NS or the NBh were originally composed and, if orally composed, when they began to be preserved and transmitted in written form. However, judging from the epistemic importance of śabda and from teaching and learning habits in traditional circles witnessed in modern times, it is possible that the performative tradition of these works was mainly oral, and that they were often memorized and taught without much reliance on writing. ${ }^{6}$ For easily memorizable works, such as those in aphorisms and verses, the written record was probably perceived as secondary. In other words, the authority of orally taught truths, passed on from teacher to pupil, was probably superior to that of written ones.

As for large and digressive works such as the NM, they were more likely composed in written form to begin with and were not commonly meant to be memorized in their entirety. If this is the case, then, also the purpose of their written transmission must have been different. In 1472 CE, Śitikanthāaārya Svāmin, the learned copyist of the oldest extant NM manuscript, wrote in his colophon (P, fol. II 271r,1) that the NM had been copied by him for teaching purposes (śișyān adhyāpayitum).

In any case, what is the epistemic role of written words for Jayanta? During his refutation of the sphota, he makes clear that written letters convey knowledge of the artha indirectly, through an inferential process:

[...] Therefore the knowledge of the artha caused by the ink traits is based on the inference of the phonemes (tasmād varñānumānapurassaraiva rekhäbhyo 'rthāvagatih).

It thus seems theoretically acceptable to consider writing as leading to an instance of epistemically effective śabda. Just like the perception of phonemes assists the hearer in knowing from śabda, so can the perception of the ink traits assist an inference of those very phonemes, which again assists the hearer in knowing from śabda. One should also keep in mind that in Nyāya epistemology the possibility of knowing one and the same object through different instruments of knowledge (pramānasamplava) is acceptable $\left(\mathrm{NM}^{\mathrm{Va}} \mathrm{I}\right.$, pp. 87-93). Furthermore, loud reading of a written source, either by the teacher to the pupils or on one's own, may also play a role in these considerations.

\section{Why did Jayanta Use Mīmāṃsā Sources?}

Before Jayanta, in Nyāya sources, there had been no focus on the sentence, with linguistic analyses mostly concerned with words and their link to external things. In NM 5 (NM ${ }^{\mathrm{Va}}$ II, pp. 135,15-136,10), after examining various theories on sentence

\footnotetext{
Footnote 5 continued

what is written survives the act of writing. So all written words exist side by side [...]". Mohanty (1994, p. 31) suggests slight modifications in the utterer-conditions to make room for written testimony as śabda.

6 This, incidentally, would also explain the absence of a manuscript tradition of the NS independent of the NBh in the early stage of the transmission.
} 
signification, Jayanta explained why he could not fully count on his own tradition on this matter, and, implicitly, why he largely drew from Mīmāṃsā theories:

[Objection:] The authors of the [Nyāya]sūtra and of the [Nyāya]bhāsya have not described the artha of the sentence anywhere: from where shall we learn about the nature of the artha of the sentence, in order to expound it? [Counterobjection:] [...] this discipline of reasoning ( $\bar{a} n v \bar{\imath} k s \underline{i k} \bar{\imath})$ is the science of means of knowledge, not the science of the artha of the sentence.

[Objection:] Yet, if such is the case, why was the artha of the word taught, [by the sütra] "the artha of the word, however, is the individual thing, [its] conformation (äkrti), [its] universal character (jāti)" [NS 2.2.66]? [Counterobjection:] This is a good point. That effort, however, was done by the author of the [Nyāya]sütra in order to establish the epistemic validity of śabda, and to calm down protests that there is no contact between śabda and artha.

[Objection:] Yet, if this is the case, without an external object as the artha of the sentence the epistemic foundation of the science would remain shaky, so an effort should be done also in this area. [Counter-objection:] True. The author of the [Nyāya]sütra, by teaching only the artha of the word, meant to take care [also] of that [artha of the sentence], so he did not teach the artha of the sentence separately from that of the word. Therefore, his idea is that the very artha of the word is the artha of the sentence; [...] not that the artha of a single word is the artha of the sentence; rather, the artha of several words is the artha of the sentence.

In this passage, Jayanta stressed the epistemic focus of the Nyāya discipline. Also, he apparently endorsed a realist epistemology in which the artha is external and real (bāhya and vāstava). Lastly, he hinted at the strategy that he was going to adopt to explain the transaction from word to sentence signification, on the one hand respecting the letter of the NS (2.2.66), were the artha of the word is defined, and on the other integrating a modified version of the Bhātța Mīmāṃsā theory of sentence signification in the Nyāya system. ${ }^{7}$

\section{Jayanta on Re-use and Originality}

In the introductory verses of the $\mathrm{NM}\left(\mathrm{NM}^{\mathrm{Va}} \mathrm{I}, \mathrm{pp} .2-4\right)$, there are further indications about Jayanta's relation with his own tradition, a source of many of his re-uses. In verse 4 he traced back the Nyāya tradition to sage Akșapāda, to whom the NS is attributed, and in verses 7-9 he portrayed the tradition of Nyāya as the source of his tenets, claiming for himself only the merit of having craftily re-ordered pre-existing notions: ${ }^{8}$

\footnotetext{
7 On the rival Mīmāmsā theories of abhihitānvaya and anvitābhidhāna, and on Jayanta's understanding of these, see Kunjunni Raja (1963, p. 215) and Graheli (forthcoming).

${ }^{8}$ Besides Jayanta, other well-known authors, such as Abhinavagupta, have portrayed themselves as mere re-arrangers of traditional tenets. This typical self-description by three heterogeneous authors such as Jayanta, Abhinavagupta, and Jīva Gosvāmin, is compared and related to the issue of novelty and repetition in Graheli (2008).
} 
This superior essence was collected in the forests of the herbs of Nyāya. It was extracted like butter from the milk of reasoning (ānvikssikì). ${ }^{9}$ How could I be capable of even envisioning a new topic? Here my only concern is a variety (vaicitrya) in arrangement of the [traditional] statements. Flower chaplets crafted in the past can generate new interest if their very flowers are recomposed on a new string.

After comparing the Nyāya system to a mighty tree cared for by Akșapāda, Jayanta depicted himself as merely capable of a partial view of its full richness:

In fact, the tall tree of logic laid down by Akșapāda bears a load of fruits oozing thick nectar. I will gently shake it, being uncapable of climbing on it. [Thus] I cannot even see its full burden of riches.

To sum up, Jayanta planned his NM as a new structure built with tenets of a rich pre-existing tradition, without any claim for originality, except for the arrangement of the presentation.

\section{The Argumentative Structure of the sphota Section of NM 6}

To examine the formal aspect of quotations and other re-uses, and to assess their epistemic value, the context of the argumentative structure is crucial. The sphota section of NM 6 can be segmented in five argumentative steps: problem, thesis, first antithesis, second antithesis, synthesis (sketched in Fig. 1).

- The topic is introduced by the philosophical problem (samśaya) that is going to be dissected and settled: in the epistemic process of knowing something upon hearing a linguistic expression, what is precisely the cause of knowledge of an artha? Is it the ephemeral phonemes, as claimed in Nyāya (pratijñ $\bar{a}$, thesis)? Or is it the indivisible entity called sphoța, as claimed in Vyākaraṇa (pūrvapakșa, first antithesis)? Or is it the permanent phonemes, as claimed in Mīmāṃāā (uttarapakșa, second antithesis)?

- The thesis is that phonemes are heard in sequence form words and sentences, and thus they collectively cause knowledge of an object, though phonemes are not permanent entities, but rather ephemeral ones.

- The first antithesis (pürvapaksa) is the solution of the problem as proposed in Vyākarana, based on Bhartrhari's holistic theory of meaning.

- The second antithesis (uttarapakșa), which refutes the first one, is the solution of the problem as proposed in Mīmāṃsā, largely based on Kumārila's atomistic arguments. $^{10}$

- The synthesis (siddhānta) consists of a minor modification of the Mīmāṃsā arguments, to suit the Nyāya needs.

\footnotetext{
9 On the evolution from Ānvīkșikī to Nyāya, see Preisendanz (2009).

10 "Atomism" and "holism" are here used as relative terms: Kumārila has an atomistic perspective in relation to Bhartrihari, but Nyāya views before Jayanta could be considered more atomist than Kumārila's. On the use of the terms "holism" and "atomism" in relation to the context and composition principles and to the Indian theories of meaning, see Matilal and Sen (1988, p. 84).
} 


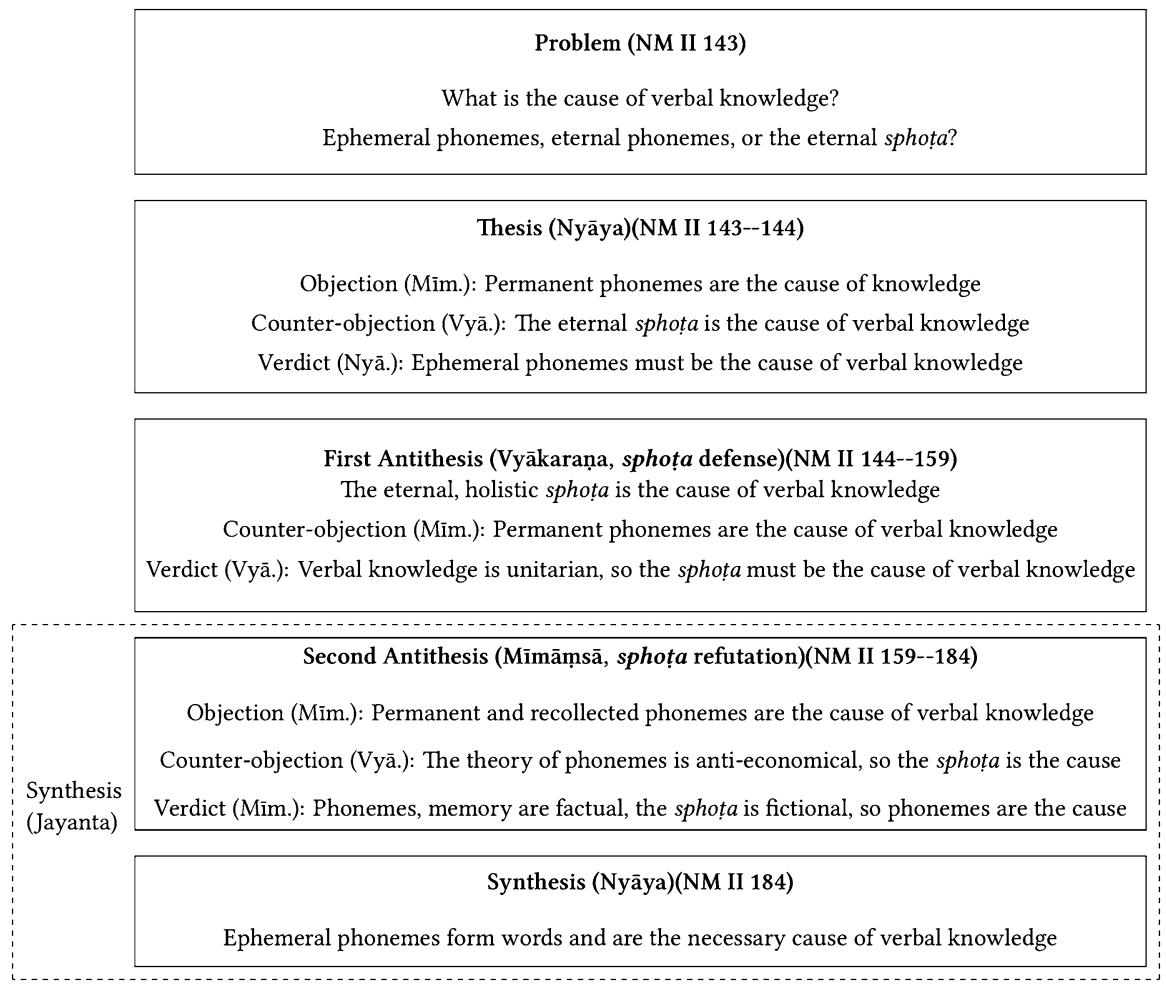

Fig. 1 Argumentative structure of the sphota section of NM 6

The thesis and the two antitheses are in turn structured in a dialogic form of progressive objections (pakșa), counter-objections (pratipakșa), and verdicts (nirnaya), so that in the first antithesis the objections and the verdicts are Bhartṛhari's, while the counter-objections are (mainly) Kumārila's; in the second antithesis the roles are reversed. The problem, the thesis, and the synthesis are presented very concisely, while the two antitheses form the bulk of the section.

\section{Re-uses in the NM}

In the following, a selection of re-uses in defense and refutation of the sphota are documented in tabular form. For pragmatic reasons, I limited myself to re-uses of the Śäbarabhāṣya (ŚBh), Ślokavārttika (ŚV), Ślokavārttikatātparyațīka (ŚVTṬ), ${ }^{11}$ and Vākyapadìya (VP). I ignored other sources such as the Bṛhatī (Bṛh) and the

11 The debt of Jayanta to Umveka's commentary is clear from many passages (see Sects. 7.1, 7.3, 7.6, 8.1 , and 8.2 below). In a number of occasions (GBh, pp. 24,14, 149,4, 182,17), Jayanta's commentator, Cakradhara, also noticed the connection and explicitly mentioned Jayanta's references to Umveka. 
Sphotasiddhi (SphS). ${ }^{12}$ The list of re-uses presented here is a selection without claims of exhaustiveness, as there are less evident re-uses which were discarded, and other possible ones that may have escaped my attention.

Re-uses are sorted according to their sequence of occurrence in the NM and are grouped in tables on the basis of the argumentative structure of the NM. Each table is contextualized by a brief synopsis of the philosophical issues at stake, and followed by some comments on the interesting features of the re-uses.

The first column contains the origin of the text re-used by Jayanta, with the reading of the most reliable edition available to me (NS, NBh, Ś ${ }^{\mathrm{Ra}}$, SVTT, VP; for quotations from parts of the ŚV not covered by ŚV ${ }^{\mathrm{Ra}}$, I used Ś $\mathrm{V}^{\mathrm{Dva}}$ instead); manuscript research on these sources, although important for a conclusive assessment, was not feasible at this stage. The second indicates the truth value (True/False) from the source viewpoint. The third, fourth and fifth columns contain the re-use as found in the NM, subclassified into three segments: the re-use (sequentially numbered for cross-reference purpose in this paper) preceded or followed by pre- and post-quote markers, when present; re-used expressions, including also differently inflected stems, are shown in bold face. Lastly, the sixth and the seventh columns indicate the truth value from the point of view of the symbolic speaker, and the tradition symbolized by the statement (Vyākaraṇa/Mīmāṃsā/Nyāya).

All the NM passages reproduced in this paper refer to the pagination of $\mathrm{NM}^{\mathrm{Va}}$. Whenever other relevant witnesses ${ }^{13}$ - namely $\mathrm{NM}^{\mathrm{Ga}}$, the Nyāyamañjarīgranthibhanga (GBh) and the important manuscripts ( $\mathrm{P}$ and $\mathrm{C}$ )- have substantive variants that differ from $\mathrm{NM}^{\mathrm{Va}}$, such readings are either received in the text or shown in critical notes below the tables.

\section{First Antithesis: Re-use in Defense of the sphota}

\subsection{Phonemes do not Cause Verbal Knowledge}

Vaiyākaraṇas maintain that phonemes cannot convey meaning, neither independently nor collectively. Independent phonemes are just meaningless parts of words. And if a word is considered a collection of phonemes, one must explain if they function simultaneously or in sequence, and both options are not tenable.

The simultaneous existence of phonemes is ruled out in (1). The only possibility of a simultaneous utterance of the phonemes composing a word would be that each

\footnotetext{
${ }^{12}$ Although in the NM there are no explicit references to Mandana or to the SphS, there are some instances that suggest some relation. The most striking one is the argument in $\mathrm{NM}^{\mathrm{Va}}, 150,13-14$, where eke, contrasted to apare, i.e. to Bhartṛhari, may refer to Mandana Miśra. The SphS, 89,4-6 reads: yathā ratnaparīkșinah parīkșamānasya prathamasamadhigamānupākhyātam anupākhyeyarūpapratyayopāhitasamskārarūpāhitavisesẹāyām buddhau kramena carame cetasi cakāsti ratnatattvam. The NM reads: yathā ratnaparīkșakānām prathamadarśane ratnarūpam amalam prakāśamānam api punah punah parīkșamānānām carame cetasi cakāsti niravadyam ratnatattvam. The terminological similarity is noteworthy. I could not find this jem/jeweller comparison in early sources, except for Vācaspati Miśra's Tattvabindu (see TB, p. 70), for which there are arguments in favor of its posteriority in respect to the NM.

13 A detailed explanation of the criteria for selecting relevant NM witnesses is provided in Graheli 2012b.
} 
of a group of speakers simultaneously utters one of the phonemes composing the word, which is absurd (2). So, since a plurality of phonemes is uttered by a single speaker, there must necessarily be a chronological sequence of phonemes in such an utterance (3) (Table 7.1).

In (1), the link with Kumārila's statement is more evident in the variant of $P$, with the reading sattā, in place of satām of the NM editions. For both opponents, as well as for Jayanta, (1) denies the possibility of the simultaneous existence of the phonemes forming a word. Although because of different reasons, for all of them it is true that by itself a group of phonemes can not cause verbal knowledge. For Mīmāmsakas śabda is permanent and thus an ontological simultaneity of phonemes is acceptable, but phonemes need to be uttered and grasped in order to be effective, and they are uttered and grasped in sequence. Also for Vaiyākaranas śabda is permanent, but an ontological simultaneity of phonemes is impossible because phonemes are ultimately fictional entities. For Naiyāyikas a simultaneous existence of phonemes is simply not possible, due to the ephemeral nature of śabda.

In (2) the absurdity of many people simultaneously pronouncing different phonemes of a same word is stated, and this is obviously shared by all. (3) is also true for everyone involved here, because if a single person utters a series of phonemes there must necessarily be a sequence.

Table 7.1 The theory of phonemes is wrong

\begin{tabular}{|c|c|c|c|c|c|c|}
\hline Source & $\begin{array}{l}\text { Truth } \\
\text { val. }\end{array}$ & $\begin{array}{l}\text { Pre- } \\
\text { quote }\end{array}$ & Re-use & $\begin{array}{l}\text { Post- } \\
\text { quote }\end{array}$ & Truth val. & $\begin{array}{l}\text { Point } \\
\text { of view }\end{array}$ \\
\hline $\begin{array}{l}\text { yaugapadyāgrhīteś ca } \\
\text { samudāyau na sidhyatah / } \\
\text { na sattāyaugapadyasya } \\
\text { vyavahārāngateșyate // } \\
\text { (ŚS }{ }^{\text {Dvāa }} \text {, vākya 7cd-8ab) }\end{array}$ & True & & 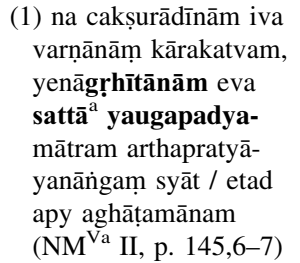 & & True & Vyā. \\
\hline $\begin{array}{l}\text { yaugapadyaṃ ca } \\
\text { śakyatvān naiva teșām } \\
\text { ihāśritam / kartṛbhedaś ca } \\
\text { tatra syān na caivaṃ } \\
\text { drśyate 'bhidhā // (Ś́ } V^{\mathrm{Ra}} \text {, } \\
\text { sphoṭa 72) }\end{array}$ & True & & $\begin{array}{l}\text { (2) tatrāneka }{ }^{\text {b}} \text { puruṣabhā- } \\
\text { șitānāṃ kolāhala- } \\
\text { svabhāvatvena } \\
\text { svarūpabheda eva } \\
\text { duravagama (NM }{ }^{\mathrm{Va}} \mathrm{II}, \\
\text { p. 145,12-13) }\end{array}$ & & True & Vyā. \\
\hline $\begin{array}{l}\text { vaktraikatve nimitte ca } \\
\text { krame sati niyāmakam / } \\
\text { prayuñjānasya yat } \\
\text { pūrvaṃ vrụddhebhyah } \\
\text { kramadarśanam; vaktur } \\
\text { ekatvāc ca varnānām } \\
\text { avaśyambhāvini krame } \\
\text { [...] (ŚV }{ }^{\text {Ra }} \text {, sphoța 71; } \\
\text { ŚVTṬ, sphoța 71) }\end{array}$ & True & & $\begin{array}{l}\text { (3) ekavaktṛpra- } \\
\text { yuktānāṃ tu } \\
\text { prayatnasthānakaraṇa- } \\
\text { kramāparityāgād } \\
\text { avaśyambhāvī } \\
\text { kramạ̣ / NM }{ }^{\mathrm{Va}} \text { II, p. } \\
\text { 145,16-17 }\end{array}$ & & True & Vyā. \\
\hline
\end{tabular}




\subsection{The Last Phoneme does not Cause Knowledge}

Conceding that phonemes do not convey meaning, neither independently nor collectively, the Mīmāmsakas argue that the perception of the last phoneme triggers verbal knowledge, while assisted by the memory of previous phonemes (4). This, however, is unacceptable, because such memory would be caused by a mental disposition (samskāra), which would be in turn produced by the perception of each phoneme. But memory and mental dispositions are not accepted as instruments of valid knowledge, so this theory is not sound (Table 7.2).

The tenet expressed here is true for Mīmāṃsakas, but false for Vaiyākaraṇas.

Table 7.2 The theory of the last phoneme is wrong

\begin{tabular}{|c|c|c|c|c|c|c|}
\hline Source & $\begin{array}{l}\text { Truth } \\
\text { val. }\end{array}$ & Pre-quote & Re-use & Post-quote & Truth val. & $\begin{array}{l}\text { Point } \\
\text { of view }\end{array}$ \\
\hline $\begin{array}{l}\text { pūrvavarṇaja- } \\
\text { nitasaṃskārasahito } \\
\text { 'ntyo varṇaḥ } \\
\text { pratyāyakaḥ / (ŚBh ad } \\
1.1 .5 \text {, p. } 55,1-2)\end{array}$ & True & $\begin{array}{l}\text { yad apy } \\
\text { ucyate }\end{array}$ & $\begin{array}{l}\text { (4) pūrvavarṇaja- } \\
\text { nitasaṃskārasahi- } \\
\text { to 'ntyo varṇaḥ } \\
\text { pratyāyaka (NM } \\
\text { II, p. } 146,4)\end{array}$ & $\begin{array}{l}\text { iti tad apy } \\
\text { ayuktam }\end{array}$ & False & Vyā. \\
\hline
\end{tabular}

${ }^{\mathrm{a}}$ pūrva] $\mathrm{P} \mathrm{C}$; pūrvapūrva $\mathrm{NM}^{\mathrm{Va}} \bullet{ }^{\mathrm{b}}$ 'ntyo varṇaḥ] $\mathrm{P} \mathrm{C} \mathrm{NM}^{\mathrm{Ga}}$; antyavarṇaḥ $\mathrm{NM}^{\mathrm{Va}}$

\subsection{A Cognition Made of Memory and Perception is Impossible}

The passage quoted in (4) has been interpreted by Kumārila by postulating a single, variegated cognition embracing the memory of the past phonemes and the perception of the last one, to avoid the issue raised by the Vaiyākaranas, namely that memory or mental dispositions of past phonemes cannot cause valid knowledge. But, argue the Vaiyākaraṇas, such a variegated and unitary cognition is also impossible, because mental dispositions cannot possibly produce a single cognition together with sense organs: mental dispositions cause recollections, while sense organs cause perceptions (Table 7.3).

Table 7.3 The variegated cognition is impossible

\begin{tabular}{|c|c|c|c|c|c|c|}
\hline Source & $\begin{array}{l}\text { Truth } \\
\text { val. }\end{array}$ & $\begin{array}{l}\text { Pre- } \\
\text { quote }\end{array}$ & Re-use & Post-quote & $\begin{array}{l}\text { Truth } \\
\text { val. }\end{array}$ & $\begin{array}{l}\text { Point } \\
\text { of view }\end{array}$ \\
\hline $\begin{array}{l}\text { citrarūpāṃ ca tāṃ buddhiṃ } \\
\text { sadasadvarṇagocarām / } \\
\left.\text { (ŚV }{ }^{\mathrm{Ra}} \text {, sphoṭa } 111 \mathrm{ab}\right) ; \\
\text { apare tu } \\
\text { saṃskāratrayajanyām } \\
\text { varṇasmaraṇarūpāṃ } \\
\text { sańkalanātmikām icchanti } \\
\text { (ŚVTṬ, sphoṭa 112) }\end{array}$ & True & $\begin{array}{l}\text { atha } \\
\text { vadet }\end{array}$ & 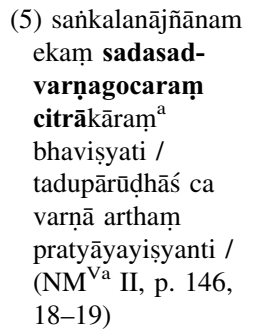 & $\begin{array}{l}\text { tad api } \\
\text { durāsāamātram }\end{array}$ & False & Vyā. \\
\hline
\end{tabular}

a citrākāraṃ] C; om. $\mathrm{NM}^{\mathrm{Ga}} \mathrm{NM}^{\mathrm{Va}} ; \mathrm{P}$ n.a 
In (5) the two concepts of a variegated (citrarūpa $)$ and cumulative (saikalanātmikā) cognition used by Kumārila and Umveka as two alternative scenarios in the theory of phonemes, seem to be reduced to a single one by Jayanta. The notion, in any case, is false from the Vaiyākaraṇas's point of view.

\subsection{Language Acquisition does not Justify the Existence of Phonemes}

In defense of the theory of phonemes, Mīmāmsakas claim that language-produced knowledge requires linguistic competence, which is acquired through the repeated observation of a given pattern of phonemes in relation to their artha (6-7) (Table 7.4).

From the Vaiyākaranas' point of view it is false that language acquisition occurs through phonemes.

\subsection{The Theory of Phonemes is not Supported by Common Usage}

People commonly say that "from śabda we know an artha", where the use of the singular, "from śabda", matches the unity of the sphota, not a plurality of phonemes (Table 7.5).

From the Vaiyākarana's point of view it is correct that common usage favors the sphota, so (8) is true. The same argument was present in the source in the form of an objection, and thus considered false there.

Table 7.4 Language acquisition does not require phonemes

\begin{tabular}{|c|c|c|c|c|c|c|}
\hline Source & $\begin{array}{l}\text { Truth } \\
\text { val. }\end{array}$ & $\begin{array}{l}\text { Pre- } \\
\text { quote }\end{array}$ & Re-use & Post-quote & $\begin{array}{l}\text { Truth } \\
\text { val. }\end{array}$ & $\begin{array}{l}\text { Point } \\
\text { of } \\
\text { view }\end{array}$ \\
\hline $\begin{array}{l}\text { sambandhagrahaṇavaśena } \\
\text { varṇānām } \\
\text { arthapratipādakatvaṃ } \\
\text { yeșāṃ ca yāvatāṃ } \\
\text { yatkramakāṇām ca yat tad } \\
\text { asti, tat teșāṃ tāvatām eva } \\
\text { tatkramakāṇām } \\
\text { ekavaktṛprayuktānāṃ ca } \\
\text { pratipādakatvam ity arthah } \\
\text { (ŚVTṬ, sphoṭa } 69 \text { ) }\end{array}$ & True & nanu & 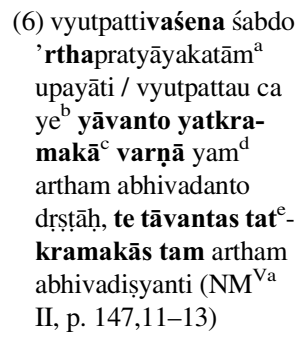 & iti & False & Vyā. \\
\hline $\begin{array}{l}\text { yāvanto yādṛsā ye ca } \\
\text { yadarthapratipādane / } \\
\text { varṇāḥ prajn̄ātasā- } \\
\text { marthyās te tathaivāvabo- } \\
\text { dhakāḥ // (ŚV }{ }^{\mathrm{Ra}} \text {, sphoța 69) }\end{array}$ & True & $\begin{array}{l}\text { tad } \\
\text { uktam }\end{array}$ & $\begin{array}{l}\text { (7) yāvanto yādṛ́s̄ā } \\
\text { ye ca yadarthapra- } \\
\text { tipādane / varṇāḥ } \\
\text { prajūātasāmar- } \\
\text { thyās te tathaivāva- } \\
\text { bodhakāḥ // (NM }{ }^{\mathrm{Va}} \mathrm{II}, \\
\text { p. 146,15-16) }\end{array}$ & $\begin{array}{l}\text { iti duravagamā } \\
\text { hi varṇavartanī }\end{array}$ & False & Vyā. \\
\hline
\end{tabular}

${ }^{\mathrm{a}}$ pratyāyakatām] $\mathrm{P} \mathrm{NM}^{\mathrm{Ga}} \mathrm{NM}^{\mathrm{Va}}$; grāhakatām $\mathrm{C} \bullet{ }^{\mathrm{b}}$ ye] $\mathrm{P} \mathrm{C} ;$ om. $\mathrm{NM}^{\mathrm{Ga}} \mathrm{NM}^{\mathrm{Va}} \cdot{ }^{\mathrm{c}}$ yatkramakā] $\mathrm{P} \mathrm{C}$ $\mathrm{NM}^{\mathrm{Ga}}$; yatkramā $\mathrm{NM}^{\mathrm{Va}} \bullet{ }^{\mathrm{d}}$ yam] $\mathrm{P} \mathrm{C} \mathrm{NM}{ }^{\mathrm{Ga}}$; yad $\mathrm{NM}^{\mathrm{Va}} \bullet{ }^{\mathrm{e}}$ tat] $\mathrm{P} \mathrm{NM} \mathrm{Na}^{\mathrm{Ga}} \mathrm{NM}^{\mathrm{Va}}$; tāvat C 
Table 7.5 The theory of phonemes goes against common usages

\begin{tabular}{|c|c|c|c|c|c|c|}
\hline Source & $\begin{array}{l}\text { Truth } \\
\text { val. }\end{array}$ & $\begin{array}{l}\text { Pre- } \\
\text { quote }\end{array}$ & Re-use & $\begin{array}{l}\text { Post- } \\
\text { quote }\end{array}$ & $\begin{array}{l}\text { Truth } \\
\text { val. }\end{array}$ & $\begin{array}{l}\text { Point } \\
\text { of view }\end{array}$ \\
\hline $\begin{array}{l}\text { nanv evam api } \\
\text { śabdād arthaṃ } \\
\text { pratipadyāmaha iti } \\
\text { laukikaṃ vacanam } \\
\text { anupapannaṃ syāt / } \\
\text { (ŚBh } 1.1 .5, \text { p. } 56,1-2 \text { ) }\end{array}$ & False & & $\begin{array}{l}\text { (8) sphotọo 'rthapratipādakah, } \\
\text { śabdād artham } \\
\text { pratipadyāmaha iti } \\
\text { vyavahārāt }\left(\mathrm{NM}^{\mathrm{Va}} \mathrm{II},\right. \\
\text { p. } 148,12)\end{array}$ & & True & Vyā. \\
\hline
\end{tabular}

\subsection{Phonemes do not Qualify as śabda}

To argue that śabda must by definition be audible, and that phonemes are audible while the sphota is not, does not make sense, because audibility is not an exclusive character of phonemes (9) (Table 7.6).

The Mìmāmsaka may argue that although it is not an exclusive characteristic, it is still the main one, and that the phonemes are audible while the sphota is not. Yet, the characteristic mark of śabda is not the mere audibility, but rather, its capacity to cause knowledge of the artha (10-11). And such character belongs to the sphota, not to phonemes.

People are erroneously led to think that phonemes are the cause of verbal knowledge only because the sphota manifests through articulated language, but actually this idea is the result of a false-cause fallacy (12) (Table 7.6).

It is false, from the Vaiyākarana's viewpoint, that the audibility of phonemes qualifies them as śabda (9).

(10) and (11) are false for the Mīmāṃsakas and true for the Vaiyākaraṇas, who have the interest of underscoring causality of cognition over audibility. (12), which is true for the Mīmāmsakas, is rejected by Vaiyākaraṇas as false.

\subsection{The Theory of the sphota is not Anti-economic}

The Mīmāmsakas object that if the sphoṭa is manifested by phonemes, as maintained by some Vaiyākaranas (see above, footnote 12 on the SphS), a criticism moved against the theory of phonemes stands also against the theory of the sphota, which basically adopts the theory of phonemes with its implications and on top of it postulates a further entity (13-14) (Table 7.7).

The economy of the theory of phonemes in (13) and (14) is true for the Mīmāmsakas, but false for the Vaiyākaraṇas.

\subsection{The sphota is Manifested by Articulated Sound}

According to other Vaiyākaranas, however, this is not true: the sphota is not manifested by phonemes, but rather by phonetic sounds (dhvani), i.e., the combined result of breath, articulation, etc., which in any case do not have ultimate ontological status (15) (Table 7.8).

From here to the end of the first antithesis, all re-uses are of Vaiyākarana texts, and thus true also in the sources. 
Table 7.6 Phonemes are not śabda

\begin{tabular}{|c|c|c|c|c|c|c|}
\hline Source & $\begin{array}{l}\text { Truth } \\
\text { val. }\end{array}$ & $\begin{array}{l}\text { Pre- } \\
\text { quote }\end{array}$ & Re-use & $\begin{array}{l}\text { Post- } \\
\text { quote }\end{array}$ & $\begin{array}{l}\text { Truth } \\
\text { val. }\end{array}$ & $\begin{array}{l}\text { Point } \\
\text { of } \\
\text { view }\end{array}$ \\
\hline $\begin{array}{l}\text { śrotragrahane hy arthe } \\
\text { loke śabdaśabdah } \\
\text { prasiddhạ (ŚBh 1.1.5, } \\
\text { p. } 54,8 \text { ) }\end{array}$ & True & nanu & $\begin{array}{l}\text { (9) śrotragrahaṇe hy } \\
\text { arthe śabdaśabdaḥ } \\
\text { prasiddhạ̣ / te ca } \\
\text { śrotragrahan̄ā iti / } \\
\left(\mathrm{NM}^{\mathrm{Va}} \mathrm{II}, \text { p. 149,4-5) }\right.\end{array}$ & $\begin{array}{r}\text { naitad } \\
\text { evam }\end{array}$ & False & Vyā. \\
\hline $\begin{array}{l}\text { ato gakārādivyatirikto } \\
\text { 'nyo gośabdo 'sti yato } \\
\text { 'rthapratipattih syāt } \\
\text { (ŚBh } 1.1 .5, \text { p. } 54,12-13 \text { ) }\end{array}$ & False & & $\begin{array}{l}\text { (10) tasmād yato } \\
\text { 'rthapratipattị̣ sa } \\
\text { śabdah / arthapratipattiś } \\
\text { ca sphotāa eva, na } \\
\text { varṇebhyah iti sphoța } \\
\text { eva śabdah / (NM }{ }^{\text {Va }} \text { II, } \\
\text { p. 149,7-8) }\end{array}$ & & True & Vyā. \\
\hline $\begin{array}{l}\text { atha gaur ity etasmin } \\
\text { vijñāne śrotre bahavo } \\
\text { 'rthāḥ pratibhāsante / tatra } \\
\text { kas teșām śabda ity } \\
\text { upakramya yenoccari- } \\
\text { tenārthapratyayo bhavati } \\
\text { sa śabda ity } \\
\text { upasaṃhṛtam / (ŚVTṬ, } \\
\text { sphoța 3) }\end{array}$ & False & & $\begin{array}{l}\text { (11) atha gaur ity atra } \\
\text { śrotre }{ }^{\mathbf{a}} \text { pratibhāse } \\
\text { bahavo 'rthāḥ } \\
\text { pratibhāsante / tatra } \\
\text { kas teșāṃ śabdạ̣ ity } \\
\text { upakramya yato } \\
\text { 'rthapratipattih sa } \\
\text { śabda ity upasaṃhṛte } \\
\left(\mathrm{NM}^{\mathrm{Va}} \mathrm{II}, \text { p. 149, }\right. \\
\text { 11-12) }\end{array}$ & & True & Vyā. \\
\hline $\begin{array}{l}\text { na gauño 'kṣareṣu } \\
\text { nimittabhāvaḥ, tadbhāve } \\
\text { bhāvāt tadabhāve } \\
\text { cābhāvāt (ŚBh 1.1.5, } \\
\text { p. 58,3-4) }\end{array}$ & True & nanu ca & $\begin{array}{l}\text { (12) iyam arthapratītir } \\
\text { varṇeșu bhavatsu } \\
\text { bhavantī teṣv } \\
\text { abhavatsu cābhavantī } \\
\left(\mathrm{NM}^{\mathrm{Va}} \mathrm{II}, \mathrm{p} .149,15\right)\end{array}$ & $\begin{array}{l}\text { ucyate / [...] } \\
\text { idam tv } \\
\text { anyathāsid- } \\
\text { dham }\end{array}$ & False & Vyā. \\
\hline
\end{tabular}

${ }^{a}$ śrotre] $\mathrm{C}, \mathrm{GBh}$; śrautre $\mathrm{P}$; śrotraja $\mathrm{NM}^{\mathrm{Ga}} \mathrm{NM}^{\mathrm{Va}}$

Table 7.7 The argument of economy is not valid

\begin{tabular}{|c|c|c|c|c|c|c|}
\hline Source & $\begin{array}{l}\text { Truth } \\
\text { val. }\end{array}$ & Pre-quote & Re-use & Post-quote & $\begin{array}{l}\text { Truth } \\
\text { val. }\end{array}$ & $\begin{array}{l}\text { Point } \\
\text { of view }\end{array}$ \\
\hline $\begin{array}{l}\text { yasyānavayavaḥ } \\
\text { sphoțo vyajyate } \\
\text { varṇabuddhibhị̣ / } \\
\text { so 'pi paryanuyogena } \\
\text { naivaitena vimucyate // } \\
\text { (ŚSV }{ }^{\mathrm{Ra}} \text {, sphoṭa } 91 \text { ) }\end{array}$ & True & $\begin{array}{c}\text { nanu }[\ldots] \\
\text { àha ca } \\
\text { bhațtah }\end{array}$ & $\begin{array}{l}\text { (13) yasyānavayavạ̣ } \\
\text { sphoṭo vyajyate } \\
\text { varṇabuddhibhị̣ / } \\
\text { so 'pi paryanuyo- } \\
\text { gena naivānena } \\
\text { vimucyata (NM }{ }^{\mathrm{Va}} \mathrm{II}, \\
\text { p. } 150,7-8)\end{array}$ & $\begin{array}{c}\text { iti [...] } \\
\text { naiṣa } \\
\text { doṣaḥ }\end{array}$ & False & Vyā. \\
\hline $\begin{array}{l}\text { nanu saṃskārakal- } \\
\text { panāyām } \\
\text { adṛștakalpanā / ucyate / } \\
\text { śabdakalpanāyāṃ sā ca } \\
\text { śabdakalpanā ca (ŚBh } \\
1.1 .5 \text {, p. 54,10) }\end{array}$ & True & bhāṣyakṛtāpi & $\begin{array}{l}\text { (14) nanu saṃskāra- } \\
\text { kalpanāyām } \\
\text { adṛșțakalpanā iti } \\
\text { āśankya prativihitạ̣ } \\
\text { śabdakalpanāyāṃ sā } \\
\text { ca śabdakalpanā ca } \\
\left(N^{\text {Va }} \text { II, p. 150,9- }\right. \\
\text { 10) }\end{array}$ & $\begin{array}{l}\text { iti naișa } \\
\text { doșaḥ }\end{array}$ & False & Vyā. \\
\hline
\end{tabular}


Table 7.8 The manifestation of the sphota

\begin{tabular}{|c|c|c|c|c|c|c|}
\hline Source & $\begin{array}{l}\text { Truth } \\
\text { val. }\end{array}$ & Pre-quote & Re-use & $\begin{array}{l}\text { Post- } \\
\text { quote }\end{array}$ & $\begin{array}{l}\text { Truth } \\
\text { val. }\end{array}$ & $\begin{array}{l}\text { Point } \\
\text { of view }\end{array}$ \\
\hline $\begin{array}{l}\text { indriyasyaiva saṃskāraḥ } \\
\text { śabdasyaivobhayasya vā / } \\
\text { kriyate dhvanibhir vādās } \\
\text { trayo 'bhivyaktivādinām // } \\
\text { (VP, 1.80) }\end{array}$ & True & $\begin{array}{l}\text { apare tu } \\
\text { vadanti }\end{array}$ & 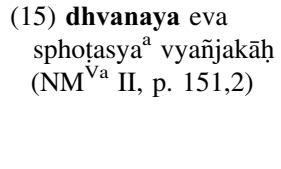 & & True & Vyā. \\
\hline
\end{tabular}

${ }^{a}$ sphoțasya] P C; sphoțasya ca $\mathrm{NM}^{\mathrm{Ga}} \mathrm{NM}^{\mathrm{Va}}$

\subsection{The Sentence is the Linguistic Unity}

Not only are phonemes unreal, even words are fictional abstractions (16). The sentence is not a whole made of parts; rather, it belongs to a class of its own (17). One may argue that there is a one-to-one correspondence between each phonemic string and its respective artha, but this is not true; for instance (18), in unrelated words like kūpa, yūpa, and süpa, we see that some phonemes are identical, yet there is no similarity in meaning (Table 7.9).

\subsection{Words are Fictional Abstractions}

The signification of words is thus a fictional device, like that of roots and suffixes. Words are an abstraction, useful for didactic purposes, etc., but devoid of ontological status (19-20) (Table 7.10).

Table 7.9 The vākyasphoța

\begin{tabular}{|c|c|c|c|c|c|c|}
\hline Source & $\begin{array}{l}\text { Truth } \\
\text { val. }\end{array}$ & $\begin{array}{l}\text { Pre- } \\
\text { quote }\end{array}$ & Re-use & $\begin{array}{l}\text { Post- } \\
\text { quote }\end{array}$ & $\begin{array}{l}\text { Truth } \\
\text { val. }\end{array}$ & $\begin{array}{l}\text { Point } \\
\text { of view }\end{array}$ \\
\hline $\begin{array}{l}\text { padāni vākye tāny eva varṇās } \\
\text { te ca pade yadi / varṇeșu } \\
\text { varṇabhagānām bhedạ̣ syāt } \\
\text { paramāṇuvat // (VP, 2.28) }\end{array}$ & True & & $\begin{array}{l}\text { (16) avayavakalpanāyāṃ hi } \\
\text { yathā vākyasyāvayavāḥ } \\
\text { padāni, padānām avayavā } \\
\text { varṇāḥ, evaṃ varṇānām } \\
\text { apy avayavair bhavitavyam / } \\
\left.\text { (NM }{ }^{\text {Va }} \text { II, p. } 153,12-13\right)\end{array}$ & & True & Vyā. \\
\hline $\begin{array}{l}\text { gavaye narasiṃhe cāpy } \\
\text { ekajñānād ṛte yathā / bhāgaṃ } \\
\text { jātyantarasyaiva sadṛśam } \\
\text { pratipadyate // } \\
(\mathrm{VP}, 2.90)\end{array}$ & True & & $\begin{array}{l}\text { (17) artho ' } \mathrm{pi}^{\mathrm{a}} \text { vākyasyaika eva } \\
\text { narasiṃhākārạ / jātyan- } \\
\text { taram hi narasiṃho nāma / } \\
\text { na tatra }{ }^{\mathrm{b}} \text { narārtho nāpi siṃhā- } \\
\text { rthạ̣ / (NM }{ }^{\mathrm{Va}} \text { II, p. 154,2) }\end{array}$ & & True & Vyā. \\
\hline $\begin{array}{l}\text { na kūpasūpayūpānām anvayo } \\
\text { 'rthasya dṛ́yate / ato } \\
\text { 'rthāntaravācitvaṃ } \\
\text { saṃghātasyaiva gamyate // } \\
\text { (VP, 2.169) }\end{array}$ & True & & $\begin{array}{l}\text { (18) na, kūpayūpasūpānām }{ }^{\mathrm{c}} \\
\text { anekākșarānugame }{ }^{\mathrm{d}}{ }^{\prime} \text { py } \\
\text { arthānugamābhāvāt / }\left(\mathrm{NM}^{\mathrm{Va}}\right. \\
\text { II, p. 154,12) }\end{array}$ & & True & Vyā. \\
\hline
\end{tabular}

\footnotetext{
a 'pi] $\mathrm{P} \mathrm{NM}{ }^{\mathrm{Ga}} \mathrm{Va}$; 'pi ca C $\bullet{ }^{\mathrm{b}}$ na tatra] $\mathrm{P} \mathrm{C} \mathrm{NM}{ }^{\mathrm{Ga}}$; tatra na $\mathrm{NM}^{\mathrm{Va}} \bullet{ }^{\mathrm{c}}$ yūpasūpānām] P C; sūpayūpānām
} $\mathrm{NM}^{\mathrm{Ga}} \mathrm{NM}^{\mathrm{Va}} \bullet{ }^{\mathrm{d}}$ anekākșarānugame] $\mathrm{P}$; ekākānugame C; ekākșarānugame $\mathrm{NM}^{\mathrm{Ga}} \mathrm{NM}^{\mathrm{Va}}$ 
Table 7.10 Words are abstractions

\begin{tabular}{|c|c|c|c|c|c|c|}
\hline Source & $\begin{array}{l}\text { Truth } \\
\text { val. }\end{array}$ & $\begin{array}{l}\text { Pre- } \\
\text { quote }\end{array}$ & Re-use & $\begin{array}{l}\text { Post- } \\
\text { quote }\end{array}$ & $\begin{array}{l}\text { Truth } \\
\text { val. }\end{array}$ & $\begin{array}{l}\text { Point } \\
\text { of view }\end{array}$ \\
\hline $\begin{array}{l}\text { yathā pade vibhajyante } \\
\text { prakrtipratyayādayaḥ / } \\
\text { apoddhāras tathā vākye } \\
\text { padānām upapadyate // } \\
\text { (VP, 2.10) }\end{array}$ & True & & $\begin{array}{l}\text { (19) kalpanāmātraṃ tv etad } \\
\text { iyaṃ prakṛtir eșa } \\
\text { pratyaya iti / evạ̄ } \\
\text { padānām api vākyāt } \\
\text { kalpanayaiva a apoddhārah / } \\
\left(\mathrm{NM}^{\mathrm{Va}} \text { II, p. 155,11) }\right.\end{array}$ & & True & Vyā. \\
\hline $\begin{array}{l}\text { apoddhrtyaiva } \\
\text { vākyebhyah } \\
\text { prakrtipratyayādivad iti // } \\
\text { (VP, } 3.1 .1 \mathrm{~cd} \text { ) }\end{array}$ & True & $\begin{array}{l}\text { tad } \\
\text { uktam }\end{array}$ & $\begin{array}{l}\text { (20) apoddhṛtyaiva }{ }^{\mathbf{b}} \\
\text { vākyebhyạ̣ } \\
\text { prakritipratyayādivad // } \\
\left(\mathrm{NM}^{\mathrm{Va}} \text { II, p. 155,12-13) }\right.\end{array}$ & iti & True & Vyā. \\
\hline
\end{tabular}

$\bar{a}$ vākyāt kalpanayaiva] C; vākyāt kalpanayoddhārạ̣ P; vākyārthaparikalpanayaiva $\mathrm{NM}^{\mathrm{Ga}} \mathrm{NM}^{\mathrm{Va}}$ • b apoddhṛtyaiva] C GBh; padaṃ kaiścid dvidhā bhinnaṃ caturdhā pañcadhāpi vā / apoddhṛtyaiva $P$ $\mathrm{NM}^{\mathrm{Ga}} \mathrm{NM}^{\mathrm{Va}}$

In (20), remarkably, while in C and GBh only the second hemistich of VP 3.1.1 is present, in $\mathrm{P}$ and in the vulgata also the first hemistich is present. $\mathrm{C}$ and $\mathrm{GBh}$, when reading together, are evidence of an earlier stage of the NM transmission.

Table 7.11 The absolute unity, śabda

\begin{tabular}{|c|c|c|c|c|c|c|}
\hline Source & $\begin{array}{l}\text { Truth } \\
\text { val. }\end{array}$ & $\begin{array}{l}\text { Pre- } \\
\text { quote }\end{array}$ & Re-use & $\begin{array}{l}\text { Post- } \\
\text { quote }\end{array}$ & $\begin{array}{l}\text { Truth } \\
\text { val. }\end{array}$ & $\begin{array}{l}\text { Point } \\
\text { of view }\end{array}$ \\
\hline $\begin{array}{l}\text { anādinidhanam brahma } \\
\text { śabdatattvaṃ yad } \\
\text { akșaram / vivartate } \\
\text { 'rthabhāvena prakriyā } \\
\text { jagato yataḥ // }(\mathrm{VP}, 1.1)\end{array}$ & True & & $\begin{array}{l}\text { (21) śabdabrah- } \\
\text { maivedam advayam }{ }^{\mathrm{a}} \\
\text { anādyavidyāvāsanopa- } \\
\text { plavamānabhedam } \\
\text { arthabhāvena } \\
\text { vivartate / }\left(\mathrm{NM} \mathrm{Va}^{\mathrm{Va}} \mathrm{II}\right. \\
\text { pp. } 156,20-157,1)\end{array}$ & & True & Vyā. \\
\hline $\begin{array}{l}\text { na so 'sti pratyayo loke } \\
\text { yah śabdānugamād ṛte / } \\
\text { anuviddham iva jñānaṃ } \\
\text { sarvam śabdena bhāsate // } \\
\text { (VP, 1.131) }\end{array}$ & True & & $\begin{array}{l}\text { (22) vāgrūpatā tu }{ }^{\mathrm{b}} \text { tattvam } \\
\text { sarvatra }{ }^{\mathrm{c}} \text { pratyaye, } \\
\text { tadanapāyāt / }\left(\mathrm{NM}^{\mathrm{Va}} \mathrm{II},\right. \\
\text { p. } 157,3)\end{array}$ & & True & Vyā. \\
\hline $\begin{array}{l}\text { vāgrūpatā ced utkrāmed } \\
\text { avabodhasya śāśvatī / na } \\
\text { prakāśạ prakāśeta sā hi } \\
\text { pratyavamarśinī // (VP, } \\
\text { 1.132) }\end{array}$ & True & yathoktam & $\begin{array}{l}\text { (23) vāgrūpatā ced } \\
\text { utkrāmed avabodha- } \\
\text { sya śāśvatī / na } \\
\text { prakāśạ prakāśeta sā } \\
\text { hi pratyavamarśin̄i // } \\
\left(\mathrm{NM}^{\mathrm{Va}} \text { II, p. 157,5-6) }\right.\end{array}$ & $\mathrm{iti}^{\mathrm{d}}$ & True & Vyā. \\
\hline
\end{tabular}

\footnotetext{
${ }^{\mathrm{a}}$ advayam] $\mathrm{P} \mathrm{NM}^{\mathrm{Ga}} \mathrm{NM}^{\mathrm{Va}}$; om. $\mathrm{C} \bullet{ }^{\mathrm{b}}$ tu] $\mathrm{P} \mathrm{C}$; om. $\mathrm{NM}^{\mathrm{Ga}} \mathrm{NM}^{\mathrm{Va}} \bullet{ }^{\mathrm{c}}$ sarvatra] $\mathrm{P} \mathrm{C}$; sarva $\mathrm{NM}^{\mathrm{Ga}} \mathrm{NM}^{\mathrm{Va}} \bullet$

d iti] $\mathrm{NM}^{\mathrm{Ga}} \mathrm{NM}{ }^{\mathrm{Va}} ;$ om. P C
} 
Table 7.12 The threefold śabda

\begin{tabular}{|c|c|c|c|c|c|c|}
\hline Source & $\begin{array}{l}\text { Truth } \\
\text { val. }\end{array}$ & Pre-quote & Re-use & $\begin{array}{l}\text { Post- } \\
\text { quote }\end{array}$ & $\begin{array}{l}\text { Truth } \\
\text { val. }\end{array}$ & $\begin{array}{l}\text { Point } \\
\text { of view }\end{array}$ \\
\hline $\begin{array}{l}\text { vaikharyā madhyamāyāś } \\
\text { ca paśyantyāś caitad } \\
\text { adbhutam / } \\
\text { anekatīrthabhedāyās } \\
\text { trayyā vācah paraṃ } \\
\text { padam // (VP, 1.159) }\end{array}$ & True & & $\begin{array}{l}\text { (24) sā ceyam vāk } \\
\text { traividhyena } \\
\text { vyavasthitāa } \\
\text { avabhāsate, vaikharī } \\
\text { madhyamā paśyantī / } \\
\left(\mathrm{NM}^{\text {Va }} \text { II, p. } 157,8\right)\end{array}$ & iti & True & Vyā. \\
\hline $\begin{array}{l}\text { sthāneṣu vivṛte vāyau } \\
\text { kṛtavarṇaparigrahā / } \\
\text { vaikharī vāk prayoktṛnāạm } \\
\text { prāṇavṛttinibandhanā // } \\
\text { (VP, 1.165) }\end{array}$ & True & tad uktam & $\begin{array}{l}\text { (25) sthāneṣu vivṛte } \\
\text { vāyau kṛtavarṇa- } \\
\text { parigrahā / vaikharī } \\
\text { vāk prayokț̣̣̄ām } \\
\text { prāṇavṛttini- } \\
\text { bandhanā // }\left(\mathrm{NM}^{\mathrm{Va}}\right. \\
\text { II, p. } 157,12-13)\end{array}$ & iti & True & Vyā. \\
\hline $\begin{array}{l}\text { kevalaṃ buddhyupādānā } \\
\text { kramarūpānupātinī / } \\
\text { prāṇavrttim atikramya } \\
\text { madhyamā vāk } \\
\text { pravartate // (VP, 1.166) }\end{array}$ & True & tad uktam & $\begin{array}{l}\text { (26) kevalaṃ } \\
\text { buddhyupādānā } \\
\text { kramarūpānupātinī / } \\
\text { prāṇavṛttim } \\
\text { atikramya madhyamā } \\
\text { vāk pravartate // } \\
\left(\mathrm{NM}{ }^{\mathrm{Va}} \mathrm{II}, \text { p. } 158,1-2\right)\end{array}$ & iti & True & Vyā. \\
\hline $\begin{array}{l}\text { avibhāgā tu paśyantī } \\
\text { sarvatah̆ saṃhṛta- } \\
\text { kramā / svarūpajyotir } \\
\text { evāntah sūkṣmā vāg } \\
\text { anapāyinī // (VP, 1.167) }\end{array}$ & True & tad uktam & $\begin{array}{l}\text { (27) avibhāgāt tu } \\
\text { paśyantī sarvatạ̣ } \\
\text { saṃhṛtakramā / } \\
\text { svarūpajyotir evāntạ̣ } \\
\text { sūkṣmā vāg } \\
\text { anapāyin̄ // (NM } \\
\text { II, p. } 158,5-6)\end{array}$ & iti & True & Vyā. \\
\hline
\end{tabular}

${ }^{\mathrm{a}}$ vyavasthitā] $\mathrm{P} \mathrm{C}$; vyavasthitaiva $\mathrm{NM}^{\mathrm{Ga}} \mathrm{NM}^{\mathrm{Va}} \bullet{ }^{\mathrm{b}}$ vivṛte] $\mathrm{P} \mathrm{NM}^{\mathrm{Ga}}$ Va; vidhṛte $\mathrm{C}$

\subsection{1 Śabda is the Absolute, Indivisible Reality}

The absolute reality is an indivisible śabda, while fictional differences are nothing more than instruments to move towards an awareness of the śabda unity, or didactic means to describe language (21-23) (Table 7.11).

\subsection{The Threefold Manifestation of śabda}

Even if in reality it is one and indivisible, śabda manifests in the world of phenomena in three aspects, vaikhārī, madhyamā, and paśyantī (24-27) (Table 7.12).

\section{Second Antithesis: Re-use in the Refutation of the sphota}

With the exception of (40) below, in this section both re-uses and sources are arguments presented from the Mīmāmsaka viewpoint, so they express true concepts both in the source and in the re-use. 


\subsection{Sequential Phonemes Can Cause a Cumulative Cognition}

In response to the Vaiyākaraṇas' objections (see Table 7.1), the Mīmāṃsakas argue that the sequential utterance of phonemes is not an issue: although phonemes are uttered and grasped in sequence, they still are, collectively, the cause of verbal

Table 8.1 Sequential causes can result in a cumulative effect

\begin{tabular}{|c|c|c|c|c|c|c|}
\hline Source & $\begin{array}{l}\text { Truth } \\
\text { val. }\end{array}$ & $\begin{array}{l}\text { Pre- } \\
\text { quote }\end{array}$ & Re-use & $\begin{array}{l}\text { Post- } \\
\text { quote }\end{array}$ & $\begin{array}{l}\text { Truth } \\
\text { val. }\end{array}$ & $\begin{array}{l}\text { Point } \\
\text { of view }\end{array}$ \\
\hline $\begin{array}{l}\text { ekasādhanasaṃsthāś ca } \\
\text { vyāpārāvayavā yadā / } \\
\text { svarūpato nirīkṣyante } \\
\text { yaugapadyam asat tadā // } \\
\text { kiṃ punar bahavo bhinnā- } \\
\text { bhinnasādhanasaṃ- } \\
\text { śritāh / bhaveyur } \\
\text { yaugapadyena vyāpārāh } \\
\text { kramavartinaḥ // (Ś̉ }{ }^{\mathrm{Ra}} \text {, } \\
\text { sphoța 77-78) }\end{array}$ & True & & 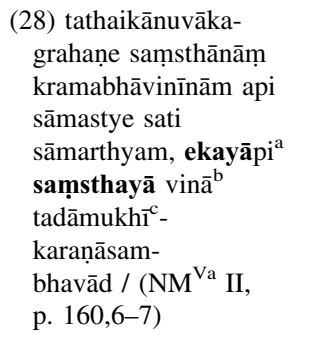 & & True & Mīm. \\
\hline $\begin{array}{l}\text { darśapūrṇamāsābhyām } \\
\text { ity upapadasamar- } \\
\text { pitasāhityetikarta- } \\
\text { vyatāviśișțānām } \\
\text { āgneyādīnām } \\
\text { ekapreryavi- } \\
\text { śeșaṇotpāda- } \\
\text { katvaṃ krameṇa, } \\
\text { karanānām āgneyādīnām } \\
\text { kṣaṇikatvena } \\
\text { yaugapadyāsambhavāt / } \\
\text { (ŚSTṬ, sphoța 74) }\end{array}$ & True & & $\begin{array}{l}\text { (29) vede 'pi } \\
\text { darśapūrṇa- } \\
\text { māsābhyām ity }{ }^{\mathrm{d}} \text { atra }^{\mathrm{e}} \\
\text { itaretarayo- } \\
\text { gaśaṃsinā dvandvena } \\
\text { samarpitasāhityānām } \\
\text { āgneyādiyāgānāṃ } \\
\text { pakșadvaya prayo- } \\
\text { jyatvena cāparihārya } \\
\text { kramāṇām ekādhikāra- } \\
\text { sampādakatvam̄ } \\
\text { dṛșțam / (NM }{ }^{\text {Va }} \text { II, } \\
\text { p. 160,8-10) }\end{array}$ & & True & Mīm. \\
\hline $\begin{array}{l}\text { abhyāse } \\
\text { caindravāyavādīnām } \\
\text { ekādhikāranișpāda- } \\
\text { katvam / loke 'pi } \\
\text { padādhyayanādīnām } \\
\text { ekānuvāka- } \\
\text { grahaṇasādhakatvam / } \\
\text { (ŚVTṬ, sphoța 74) }\end{array}$ & True & & 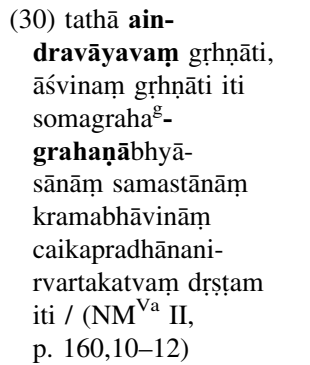 & & True & Mīm. \\
\hline
\end{tabular}

\footnotetext{
a ekayāpi] P C; ekayā $\mathrm{NM}^{\mathrm{Ga}} \mathrm{NM}^{\mathrm{Va}} \bullet{ }^{\mathrm{b}}$ vinā] $\mathrm{P} \mathrm{C} \mathrm{NM}^{\mathrm{Ga}} ;$ om. $\mathrm{NM}^{\mathrm{Va}}$ • ${ }^{\mathrm{c}}$ āmukhī] P NM ${ }^{\mathrm{Ga}} \mathrm{NM}^{\mathrm{Va}}$; abhimukhī C• ${ }^{\mathrm{d}}$ ity] $\mathrm{P} \mathrm{NM}^{\mathrm{Ga}} \mathrm{NM}^{\mathrm{Va}}$; om. $\mathrm{C} \mathrm{NM}{ }^{\mathrm{Ga}} \mathrm{NM}^{\mathrm{Va}} \bullet{ }^{\mathrm{e}}$ atra] P; om. $\mathrm{C} \mathrm{NM}^{\mathrm{Ga}} \mathrm{NM}^{\mathrm{Va}} \bullet{ }^{\mathrm{f}}$ dvaya] P C; dvaye $\mathrm{NM}^{\mathrm{Ga}} \mathrm{NM}^{\mathrm{Va}} \bullet \mathrm{g}$ graha] P C; om. $\mathrm{NM}^{\mathrm{Ga}} \mathrm{NM}^{\mathrm{Va}}$
} 
knowledge. Instances of collective and sequential causes that bring about a cumulative effect are well known, as in the case of drills to memorize verses (28) or of intermediate sacrifices (29-30) in the economy of the main one (Table 8.1).

\subsection{Dispositions and Memory in the Theory of Phonemes}

The principle that the perception of the last phoneme triggers verbal knowledge, aided by the memory of the previous phonemes (31), which was quoted and refuted by the Vaiyākaranas (see Table 7.2), actually stands valid. Objections on the capacity of dispositions to produce verbal knowledge do not hold, if we understand "mental disposition" as $v \bar{a} s a n \bar{a}$, a quality of the self. From observation we know that perceptions cause dispositions, and observation is a universal instrument of knowledge (33). And it would be silly to ask "From where does such a mental disposition arise?", because everyone knows that mental dispositions are caused by perception (34) (Table 8.2).

(31) was also quoted above (see Table 7.2). In that occasion the line in favor of atomism was not credited, unlike here. It could be because of the obviousness of the source, but it is quite likely that the absence of credits had rhetoric implications: the honorific tatrabhāvatā stresses the authoritativeness of the statement, while in

Table 8.2 Phonemes, dispositions, and memory

\begin{tabular}{|c|c|c|c|c|c|c|}
\hline Source & $\begin{array}{l}\text { Truth } \\
\text { val. }\end{array}$ & $\begin{array}{l}\text { Pre- } \\
\text { quote }\end{array}$ & Re-use & Post-quote & $\begin{array}{l}\text { Truth } \\
\text { val. }\end{array}$ & $\begin{array}{l}\text { Point } \\
\text { of } \\
\text { view }\end{array}$ \\
\hline $\begin{array}{l}\text { pūrvavarnaja- } \\
\text { nitasaṃskārasahito 'ntyo } \\
\text { varṇaḥ (ŚBh ad 1.1.5, } \\
\text { p. } 55,1-2)\end{array}$ & True & & $\begin{array}{l}\text { (31) pūrvavarṇa- } \\
\text { janitasaṃskārasahito } \\
\text { 'ntyo varṇa }{ }^{\mathrm{a}} \\
\left(\mathrm{NM}^{\mathrm{Va}} \mathrm{II}, \text { p. } 163,14\right)\end{array}$ & $\begin{array}{l}\text { iti tatrabhāvatā } \\
\text { mīmāṃsābhā- } \\
\text { șyakṛtā } \\
\text { varṇitam }\end{array}$ & True & Mīm. \\
\hline $\begin{array}{l}\text { athavā } \\
\text { gakārādivijūānajani- } \\
\text { tavāsanām evāha } \\
\text { bhāșyakārah̆ } \\
\text { saṃskāraśab̄ena / } \\
\text { tadviśișțasyai- } \\
\text { vāntyāvayava- } \\
\text { syārthapratipattau } \\
\text { hetutvaṃ } \\
\text { smaran̄ānyathānupapat- } \\
\text { tipramāṇakam / (ŚVTṬ, } \\
\text { sphoța 99) }\end{array}$ & True & & 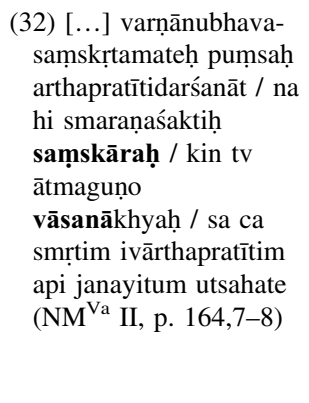 & & True & Mīm. \\
\hline $\begin{array}{l}\text { sarvatra no darśanaṃ } \\
\text { pramāṇam / (ŚBh ad } \\
1.1 .5, \text { p. } 53,1-2)\end{array}$ & True & & $\begin{array}{l}\text { (33) sarvatra no } \\
\text { darśanam pramāṇam / } \\
\left(\mathrm{NM}^{\mathrm{Va}} \mathrm{II}, \text { p. } 164,9\right)\end{array}$ & & True & N. \\
\hline $\begin{array}{l}\text { tad uktam / vastudharmo } \\
\text { hy eșa yad } \\
\text { anubhavapațīyān } \\
\text { smŕtibījam ādhatte iti / } \\
\text { (ŚVTṬ, sphoța 100, found } \\
\text { also in PSṬ, Ch. 1, Part } 1 \text {, } \\
\text { 1.5, p. } 49,10 \text { ) }\end{array}$ & True & $\begin{array}{l}\text { tathā } \\
\text { cāhuḥ }\end{array}$ & $\begin{array}{l}\text { (34) vastudharmo hy } \\
\text { eșa, yad anubhavaḥ } \\
\text { pațiyān smṛtibījam } \\
\text { ãdhatte / (NM }{ }^{\text {Va }} \text { II, } \\
\text { p. } 164,18-19)\end{array}$ & iti & True & Mīm. \\
\hline
\end{tabular}

\footnotetext{
a 'ntyo varṇa-] P C; 'ntyavarṇa $\mathrm{NM}^{\mathrm{Ga}} \mathrm{NM}^{\mathrm{Va}}$
} 
the previous case, where the argument is developed from the Vaiyākaranas' perspective, the authoritativeness of the source was meant to be undermined.

In (32) Jayanta gives a Vaiśeșika twist to the word samskāra used by Śabara, interpreting it as the quality of the self called $v \bar{a} s a n \bar{a}$. The latter term is also used by Umveka in the immediate context.

\subsection{The Theory of Phonemes is More Economical}

Alternatively, the Mīmāmsakas may concede that mental dispositions do not cause knowledge of the artha directly. Yet, they can do it through memory: mental dispositions of the past individual phonemes in sequence, together with the perception of the last one, cause a new mental disposition that produces the memory of the full word, which in turn causes the knowledge of the artha. When the Vaiyākaraṇas argue that this theory is anti-economical, the Mīmāmssakas, with Śabara, reply that they are postulating a single entity (the mental disposition), while the Vaiyākaranas necessarily must postulate two (the sphota and the mental dispositions, through which the sphoța manifests) (35).

When the Vaiyākaranas claim that, at least, they did not violate the law that mental dispositions cause only memory, the Mīmāmsakas reply that they did indeed violate it, because when they deal with the cause of the manifestation of the sphota (see Table 7.8), they have to explain it in a similar way. In addition, they postulate the sphota (36).

And the explanation of the gradual manifestation of the sphota does not hold, because knowledge of an artha is not a gradual, but rather a sudden phenomenon (37) (Table 8.3).

Table 8.3 The economy of the theory of phonemes

\begin{tabular}{|c|c|c|c|c|c|c|}
\hline Source & $\begin{array}{l}\text { Truth } \\
\text { val. }\end{array}$ & Pre-quote & Re-use & $\begin{array}{l}\text { Post- } \\
\text { quote }\end{array}$ & $\begin{array}{l}\text { Truth } \\
\text { val. }\end{array}$ & $\begin{array}{l}\text { Point } \\
\text { of } \\
\text { view }\end{array}$ \\
\hline $\begin{array}{l}\text { śabdakalpanāyām } \\
\text { sā ca śabdakalpanā } \\
\text { ca / (ŚBh ad 1.1.5, } \\
\text { p. } 54,10)\end{array}$ & True & $\begin{array}{l}\text { uktam atra } \\
\text { sugṛhī } \\
\text { tanāmnā } \\
\text { bhāṣyakāreṇa }\end{array}$ & $\begin{array}{l}\text { (35) śabdakalpanāyāṃ } \\
\text { sā ca śabdakalpanā } \\
\text { ca }\left(\mathrm{NM}^{\mathrm{Va}} \mathrm{II}, \mathrm{p} .166,3\right)\end{array}$ & iti & True & $\begin{array}{l}\text { bhā- } \\
\text { șyakāra } \\
\text { (Mīm.) }\end{array}$ \\
\hline $\begin{array}{l}\text { sadbhāvavyatirekau } \\
\text { ca tathāvayavavarja- } \\
\text { nam / tavādhikaṃ } \\
\text { bhavet tasmād yatno } \\
\text { 'sāv arthabuddhiṣu // } \\
\text { (ŚV }{ }^{\mathrm{Ra}} \text {, sphoța 94) }\end{array}$ & True & tad uktam & $\begin{array}{l}\text { (36) sadbhāvavyatirekau } \\
\text { ca tathāvayavavarja- } \\
\text { nam / tavādhikạ̣ } \\
\text { bhavet tasmād yatno } \\
\text { 'sāv arthabuddhișu // } \\
\left(\mathrm{NM}^{\mathrm{Va}} \mathrm{II}, \mathrm{p} .167,1-2\right)\end{array}$ & iti & True & Mīm. \\
\hline $\begin{array}{l}\text { alpīyasāpi yatnena } \\
\text { śabdam uccaritaṃ } \\
\text { matiḥ / yadi vā naiva } \\
\text { gṛhn̄ti varṇam vā } \\
\text { sakalam sphuțam // } \\
\left.\text { (ŚS }{ }^{\mathrm{Ra}} \text {, sphoṭa } 10\right)\end{array}$ & True & yathoktam & $\begin{array}{l}\text { (37) alpīyasāpi yatnena } \\
\text { śabdam uccaritama } \\
\text { matị̣ / yadi vā naiva } \\
\text { grhṇāti varṇam vā } \\
\text { sakalam sphuțam // } \\
\left(\mathrm{NM}^{\mathrm{Va}} \text { II, p. } 167,\right. \\
11-12)\end{array}$ & & True & Mīm. \\
\hline
\end{tabular}

a uccaritam] P C; uccāritam $\mathrm{NM}^{\mathrm{Ga}} \mathrm{NM}^{\mathrm{Va}}$ 


\subsection{The Sequence is a Property of Phonemes}

The sequence is just a property of phonemes, so no entity needs to be postulated in addition to the phonemes (38) (Table 8.4).

\subsection{The sphota does not Qualify as śabda}

Phonemes are the only basic linguistic elements, other fictional entities are not required (39); śabda is said to be of two types, articulated and not articulated, and the sphota is neither of these two (40) (Table 8.5).

(40) is one of the rare cases, in NM 6, in which Jayanta quotes from his own tradition.

Table 8.4 The sequence is not a separate entity

\begin{tabular}{|c|c|c|c|c|c|c|}
\hline Source & $\begin{array}{l}\text { Truth } \\
\text { val. }\end{array}$ & $\begin{array}{l}\text { Pre- } \\
\text { quote }\end{array}$ & Re-use & $\begin{array}{l}\text { Post- } \\
\text { quote }\end{array}$ & $\begin{array}{l}\text { Truth } \\
\text { val. }\end{array}$ & $\begin{array}{l}\text { Point } \\
\text { of view }\end{array}$ \\
\hline $\begin{array}{l}\text { dvaye saty api tenātra } \\
\text { vijñeyo 'rthasya vācakaḥ / } \\
\text { varṇāh kiṃ nu } \\
\text { kramopetāh kim nu } \\
\text { varṇāśrayạ̣ kramaḥ // } \\
\text { kramaḥ kramavatām } \\
\text { angam iti kiṃ } \\
\text { yuktisādhyāā / } \\
\text { dharmamātram asau } \\
\text { teșām na vastvantaram } \\
\text { ișyate // (ŚS }{ }^{\text {Dvā }} \\
\text { śabdanityatā 285-286) }\end{array}$ & True & $\begin{array}{l}\text { tatra } \\
\text { coktam }\end{array}$ & $\begin{array}{l}\text { (38) dvaye saty api } \\
\text { tenātra vijñeyo } \\
\text { 'rthasya vācakạ̣ / } \\
\text { varṇạ̣̄ kị̣ nu } \\
\text { kramopetāḥ kiṃ nu } \\
\text { varṇāśrayạ̣ } \\
\text { kramạ̣ // kramạ̣ } \\
\text { kramavatām añgam iti } \\
\text { kị̣ yuktisādhyatā / } \\
\text { dharmamātram asau } \\
\text { teșāṃ na vastvanta- } \\
\text { ram iṣyate // (NM }{ }^{\mathrm{Va}} \mathrm{II}, \\
\text { p. 169,12-15) }\end{array}$ & & True & Mīm. \\
\hline
\end{tabular}

Table 8.5 The sphota is not śabda

\begin{tabular}{|c|c|c|c|c|c|c|}
\hline Source & $\begin{array}{l}\text { Truth } \\
\text { val. }\end{array}$ & Pre-quote & Re-use & $\begin{array}{l}\text { Post- } \\
\text { quote }\end{array}$ & $\begin{array}{l}\text { Truth } \\
\text { val. }\end{array}$ & $\begin{array}{l}\text { Point } \\
\text { of view }\end{array}$ \\
\hline $\begin{array}{l}\text { parasparānapekșāśs } \\
\text { ca śrotrabuddhyā } \\
\text { svarūpatah / varṇā } \\
\text { evāvasīyante na } \\
\text { pūrvāparavastunī // } \\
\text { (ŚV }{ }^{\mathrm{Ra}} \text {, sphoța 9) }\end{array}$ & True & tad uktam & 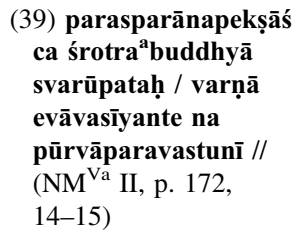 & iti & True & Mīm. \\
\hline $\begin{array}{l}\text { dvividhaś cāyam śabdo } \\
\text { varn̄ātmā dhvanimātraś } \\
\text { ca / (NBh ad 2.2.40) }\end{array}$ & True & $\begin{array}{l}\text { tad uktam } \\
\text { bhāṣyakṛ̂āa }\end{array}$ & $\begin{array}{l}\text { (40) dvividhaś cāyaṃ } \\
\text { śabdo varṇātmā } \\
\text { dhvanimātraś ca } \\
\left(\mathrm{NM}^{\mathrm{Va}} \mathrm{II}, \mathrm{p} .173,7\right)\end{array}$ & iti & True & $\begin{array}{l}\text { bhāṣyakṛt } \\
\text { (Nyā.) }\end{array}$ \\
\hline
\end{tabular}

\footnotetext{
a śrotra] $\mathrm{P} \mathrm{C} \mathrm{NM}{ }^{\mathrm{Ga}}$; śrautra $\mathrm{NM}^{\mathrm{Va}} \cdot{ }^{\mathrm{b}}$ cāyam] $\mathrm{P} \mathrm{NM}^{\mathrm{Ga}} \mathrm{NM}^{\mathrm{Va}}$; tv ayam $\mathrm{C}$
} 
Table 8.6 The smallest unity of śabda

\begin{tabular}{|c|c|c|c|c|c|c|}
\hline Source & $\begin{array}{l}\text { Truth } \\
\text { val. }\end{array}$ & $\begin{array}{l}\text { Pre- } \\
\text { quote }\end{array}$ & Re-use & $\begin{array}{l}\text { Post- } \\
\text { quote }\end{array}$ & $\begin{array}{l}\text { Truth } \\
\text { val. }\end{array}$ & $\begin{array}{l}\text { Point } \\
\text { of } \\
\text { view }\end{array}$ \\
\hline $\begin{array}{l}\text { śaighryād alpāntaratvāc ca } \\
\text { gośabde sā bhaved api / } \\
\text { devadattādiśabdeșu sphuțo } \\
\text { bhedah pratīyate // (Ś } \mathrm{V}^{\mathrm{Ra}} \text {, } \\
\text { sphoṭa 121) }\end{array}$ & True & & $\begin{array}{l}\text { (41) bhinnājupaśleșe tu } \\
\text { devadatta ity ādau } \\
\text { nānākșaragrahaṇam eva } \\
\text { vilambitam anubhūyate / } \\
\text { (NM }{ }^{\mathrm{Va}} \text { II, p. 174,12-13) }\end{array}$ & & True & Mīm. \\
\hline $\begin{array}{l}\text { alpīyasāpi yatnena śabdam } \\
\text { uccaritam matih / yadi vā naiva } \\
\text { gṛhṇāti varṇam vā sakalaṃ } \\
\left.\text { sphuțam // (ŚV }{ }^{\mathrm{Ra}} \text {, sphoța } 10\right)\end{array}$ & True & $\begin{array}{l}\text { sūktam } \\
\text { hy etat }^{\mathrm{i}}\end{array}$ & $\begin{array}{l}\text { (42) alpīyasāpi yatnena } \\
\text { śabdam uccaritaṃ } \\
\text { matị̣ / yadi vā naiva } \\
\text { gṛhṇāti varṇaṃ vā } \\
\text { sakalam sphuțam // } \\
\left(\mathrm{NM}^{\mathrm{Va}} \text { II, p. } 179,17-18\right)\end{array}$ & & True & Mīm. \\
\hline
\end{tabular}

${ }^{\mathrm{a}}$ sūktam hy etat] $\mathrm{P}$; uktam hy etat $\mathrm{C}$; tathā hy uktam etat $\mathrm{NM}^{\mathrm{Va}} \bullet{ }^{\mathrm{b}}$ uccaritaṃ] $\mathrm{P} \mathrm{C}$; uccāritam $\mathrm{NM}^{\mathrm{Ga}}$
$\mathrm{NM}^{\mathrm{Va}}$

\subsection{The Smallest śabda Unity is the Phoneme}

While in short words such as "cow" there is an impression of unity due to the brevity of the sound, there are many long words, such as "Devadatta" where the differences of sounds composing the word are clearly audible (41).

The Vaiyākaranas proposed the reductio ad absurdum that if sentences are made of words and words are made of phonemes, also phonemes must have parts. But parts of phonemes are never perceived: a phoneme is either fully perceived, or it is not perceived at all (42) (Table 8.6).

Table 9.1 Re-uses from the NS

\begin{tabular}{|c|c|c|c|c|c|c|}
\hline Source & $\begin{array}{l}\text { Truth } \\
\text { val. }\end{array}$ & Pre-quote & Re-use & $\begin{array}{l}\text { Post- } \\
\text { quote }\end{array}$ & $\begin{array}{l}\text { Truth } \\
\text { val. }\end{array}$ & $\begin{array}{l}\text { Point } \\
\text { of view }\end{array}$ \\
\hline $\begin{array}{l}\text { pratyakșānumāno- } \\
\text { pamānaśabdāḥ } \\
\text { pramāṇāni } \\
\text { (NS, p. 1.1.4) }\end{array}$ & True & $\begin{array}{l}\text { tad āha } \\
\text { sūtrakārah }\end{array}$ & $\begin{array}{l}\text { (43) pratyakṣā- } \\
\text { numāno- } \\
\text { pamānaśabdāḥ } \\
\text { pramāṇāni // } \\
\left(\mathrm{NM}^{\mathrm{Va}} \mathrm{I}, \mathrm{p} .71,6\right)\end{array}$ & & True & Akșapāda \\
\hline $\begin{array}{l}{[\ldots] \text { tattvajūānān }} \\
\text { nihśŕreyasādhi- } \\
\text { gamaḥ } \\
\text { (NS, p. 1.1.1) }\end{array}$ & True & $\begin{array}{l}\text { akșapādas } \\
\text { tāvad evam } \\
\text { upadișțavān }\end{array}$ & $\begin{array}{l}\text { (44) ātmajñānān } \\
\text { niḥ́śreyasādhi- } \\
\text { gamạ̣ (NM }^{\text {Va }} \text { II, } \\
\text { p. 461,9-10) }\end{array}$ & iti & True & Akșapāda \\
\hline $\begin{array}{l}\text { tattvādhya- } \\
\text { vasyāyasaṃra- } \\
\text { kșaṇārthaṃ } \\
\text { jalpavitaṇḍe } \\
\text { bījaprarohasam- } \\
\text { rakṣaṇārthaṃ } \\
\text { kaṇțakaśākhā- } \\
\text { varaṇavat } \\
\text { (NS, p. 4.2.50) }\end{array}$ & True & $\begin{array}{l}\text { samāhitam etad } \\
\text { bhagavatā } \\
\text { sūtrakāreṇaiva }\end{array}$ & $\begin{array}{l}\text { (45) tattvādhya- } \\
\text { vasyāyasaṃrakṣa- } \\
\text { ṇārthaṃ jalpa- } \\
\text { vitaṇḍe bījapraro- } \\
\text { hasạnrakṣa- } \\
\text { ṇārthạ̣ kaṇtaka- } \\
\text { sāāhāparivara- } \\
\text { ṇavat (NM }{ }^{\text {Va }} \text { II, } \\
\text { p. 648,3-4) }\end{array}$ & $\begin{array}{l}\text { iti } \\
\text { vadatā }\end{array}$ & True & Akșapāda \\
\hline
\end{tabular}


Table 9.2 Uncredited re-uses from the NBh

\begin{tabular}{|c|c|c|c|c|c|c|}
\hline Source & $\begin{array}{l}\text { Truth } \\
\text { val. }\end{array}$ & $\begin{array}{l}\text { Pre- } \\
\text { quote }\end{array}$ & Re-use & $\begin{array}{l}\text { Post- } \\
\text { quote }\end{array}$ & $\begin{array}{l}\text { Truth } \\
\text { val. }\end{array}$ & $\begin{array}{l}\text { Point } \\
\text { of view }\end{array}$ \\
\hline $\begin{array}{l}\text { tattvasya jñānaṃ } \\
\text { niḥśreyasasyādhi- } \\
\text { gama iti ca karmaṇi } \\
\text { șașțyau }(\mathrm{NBh} \text { ad } \\
1.1 .1, \text { p. } 2,11)\end{array}$ & True & & $\begin{array}{l}\text { (46) tattvasya jñānaṃ } \\
\text { niḥśreya- } \\
\text { syādhigama iti } \\
\text { karmaṇi ṣașțyau } \\
\left(\mathrm{NM}^{\mathrm{Va}} \mathrm{I}, \text { p. } 19,7\right)\end{array}$ & & True & Nyā. \\
\hline $\begin{array}{l}\text { saṃśayādayo hi } \\
\text { yathāsambhavaṃ } \\
\text { pramāneșu prameyeșu } \\
\text { cāntarbhavanto }(\mathrm{NBh} \\
\text { ad } 1.1 .1, \text { p. } 2,17-18)\end{array}$ & True & & $\begin{array}{l}\text { (47) saṃśayādayas tu } \\
\text { padārthā } \\
\text { yathāsambhavaṃ } \\
\text { pramāṇeșu } \\
\text { prameyeșu }^{\text {a ca }}{ }^{\mathrm{b}} \\
\left.\text { antarbhavanto }^{\text {Va }} \text { (NM } 23,1-2\right)\end{array}$ & & True & Nyā. \\
\hline $\begin{array}{l}\text { tatra nānupalabdhe na } \\
\text { nirnīite 'rthe nyāyah } \\
\text { pravartate / kiṃ tarhi / } \\
\text { saṃśayite 'rthe / } \\
\text { (NBh ad 1.1.1, } \\
\text { p. 3,3-4) }\end{array}$ & True & & $\begin{array}{l}\text { (48) tatra } \\
\text { nānupalabdhe 'rthe } \\
\text { na nirṇīte } \\
\text { pravartate / kị̣ tu } \\
\text { saṃśayite nyāyas } \\
\text { tadañgaṃ tena } \\
\text { saṃśayặ // (NM }{ }^{\mathrm{Va}} \mathrm{I}, \\
\text { p. 23,4-5) }\end{array}$ & & True & Nyā. \\
\hline $\begin{array}{l}\text { trividhā cāsya } \\
\text { śāstrasya pravṛttir } \\
\text { uddeśo lakșaṇạ̣ } \\
\text { parīksāa ceti / tatra } \\
\text { nāmadheyena } \\
\text { padārthamātrasyā- } \\
\text { bhidhānam uddeśaḥ / } \\
\text { uddișțasya } \\
\text { tattvavyavasthāpako } \\
\text { dharmo lakṣaṇam / } \\
\text { lakșitasya } \\
\text { yathālakṣaṇam } \\
\text { upapadyate na veti } \\
\text { pramāṇair } \\
\text { avadhāraṇam parīkșā / } \\
\text { (NBh ad 1.1.1, p. 8,7- } \\
\text { 9) }\end{array}$ & True & & 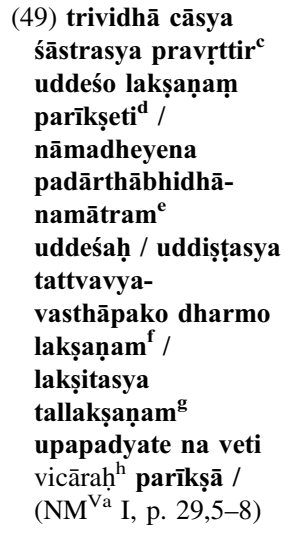 & & True & Nyā. \\
\hline
\end{tabular}

a pramāṇeșu prameyeșu] $\mathrm{C} \mathrm{NM}^{\mathrm{Ga}} \mathrm{NM}^{\mathrm{Va}}$; prameyapramāṇeșu $\mathrm{P} \bullet{ }^{\mathrm{b}}$ ca] $\mathrm{C} \mathrm{NM}^{\mathrm{Ga}} \mathrm{NM}^{\mathrm{Va}} ;$ om. $\mathrm{P}$ • c pravṛttir] $\mathrm{C} \mathrm{NM}{ }^{\mathrm{Ga}} \mathrm{NM}^{\mathrm{Va}}$; gatị̣ $\mathrm{P} \bullet{ }^{\mathrm{d}}$ parīkșeti] $\mathrm{P} \mathrm{C}$; parīkșā ceti $\mathrm{NM}^{\mathrm{Ga}} \mathrm{NM}^{\mathrm{Va}} \bullet{ }^{\mathrm{e}}$ mātram] $\mathrm{C}$; om. $\mathrm{P}$ $\mathrm{NM}^{\mathrm{Ga}} \mathrm{NM}^{\mathrm{Va}} \bullet{ }^{\mathrm{f}}$ dharmo lakșaṇam] $\mathrm{P} \mathrm{NM}^{\mathrm{Ga}} \mathrm{NM}^{\mathrm{Va}}$; dharmopalakșaṇam $\mathrm{C} \bullet \mathrm{g}$ tallakșanam] $\mathrm{C} \mathrm{NM}^{\mathrm{Ga}}$ $\mathrm{NM}^{\mathrm{Va}}$; tallakșaṇam idam $\mathrm{P} \bullet \mathrm{h}$ vicārah] $\mathrm{C} \mathrm{NM}^{\mathrm{Ga}} \mathrm{NM}^{\mathrm{Va}}$; om. $\mathrm{P}$ 
Table 9.3 Credited re-uses from the NBh

\begin{tabular}{|c|c|c|c|c|c|c|}
\hline Source & $\begin{array}{l}\text { Truth } \\
\text { val. }\end{array}$ & Pre-quote & Re-use & $\begin{array}{l}\text { Post- } \\
\text { quote }\end{array}$ & $\begin{array}{l}\text { Truth } \\
\text { val. }\end{array}$ & $\begin{array}{l}\text { Point } \\
\text { of view }\end{array}$ \\
\hline $\begin{array}{l}\text { pradīpah } \\
\text { sarvavidyānām } \\
\text { upāyaḥ } \\
\text { sarvakarmaṇām / } \\
\text { àśrayặ } \\
\text { sarvadharmān̄ām } \\
\text { vidyoddeśe } \\
\text { prakīrtitā // (NBh ad } \\
\text { 1.1.1, p. 5,19-20) }\end{array}$ & True & $\begin{array}{l}\text { āha ca } \\
\text { bhāṣyakārah }\end{array}$ & $\begin{array}{l}\text { (50) pradīpạ̣ } \\
\text { sarvavidyānām } \\
\text { upāyaḥ sarva- } \\
\text { karmaṇām / } \\
\text { āśrayạ̣ sarva- } \\
\text { dharmāṇāṃ } \\
\text { vidyoddeśe } \\
\text { parīkșitā // (NM }{ }^{\mathrm{Va}} \mathrm{I}, \\
\text { p. } 28,14-15)\end{array}$ & iti & True & $\begin{array}{c}\text { Vātsyā- } \\
\text { yana }\end{array}$ \\
\hline $\begin{array}{l}\text { agnir āptopadeśāt } \\
\text { pratīyate amutrāgnir } \\
\text { iti / pratyāsīdatā } \\
\text { dhūmadar- } \\
\text { śanenānumīyate / } \\
\text { pratyāsannena ca } \\
\text { pratyakṣata } \\
\text { upalabhyate / } \\
\text { vyavasthā punaḥ } \\
\text { agnihotraṃ juhuyāt } \\
\text { svargakāma iti / } \\
\text { laukikasya svarge na } \\
\text { lingadarśanaṃ na } \\
\text { pratyakṣam / } \\
\text { stanayitnuśabde } \\
\text { śrūyamāṇe } \\
\text { śabdahetāv } \\
\text { anumānam / tatra na } \\
\text { pratyakṣaṃ nāgamaḥ / } \\
\text { pāṇau pratyakṣata } \\
\text { upalabhyamāne } \\
\text { nānumānam nāgama } \\
\text { iti / (NBh ad 1.1.3, p. } \\
9,11-16)\end{array}$ & True & $\begin{array}{l}\text { tad } \\
\text { udāhāraṇam - } \\
\text { tu bhāṣya- } \\
\text { kāraḥ } \\
\text { pradarśitavān }\end{array}$ & $\begin{array}{l}\text { (51) agnir } \\
\text { āptopadeśāt } \\
\text { pratīyate 'mutreti / } \\
\text { pratyāsīdatā } \\
\text { dhūmadarśanenā- } \\
\text { numīyate / } \\
\text { pratyāsannatareṇa } \\
\text { upalabhyata ityādi / } \\
\text { kvacit tu vyavasthā } \\
\text { dṛśyate yathā } \\
\text { agnihotrạ̄ juhuyāt } \\
\text { svargakāma iti } \\
\text { asmadāder āgamād } \\
\text { eva jñānam, na } \\
\text { pratyakșā- } \\
\text { numānābhyām / } \\
\text { stanayitnuśab- } \\
\text { daśravan̄āt } \\
\text { taddhetuparijñānam } \\
\text { anumānād eva, na } \\
\text { pratyakșāga- } \\
\text { mābhyām / } \\
\text { svahastādau tu } \\
\text { pratyakșād eva } \\
\text { pratītih, na } \\
\text { śabdānumānā- } \\
\text { bhyām (NM }{ }^{\text {Va }} \text { I, p. } \\
\text { 93,5-13) }\end{array}$ & iti & True & $\begin{array}{c}\text { Vātsyā- } \\
\text { yana }\end{array}$ \\
\hline $\begin{array}{l}\text { yat punar anumānam } \\
\text { pratyakșāga- } \\
\text { maviruddhaṃ } \\
\text { nyāyābhāsặ sa iti } \\
\text { (NBh ad } 1.1 .1 \text {, } \\
\text { p. 3,13-14) }\end{array}$ & True & $\begin{array}{l}\text { bhāṣyakāreṇa } \\
\text { uktam }\end{array}$ & $\begin{array}{l}\text { (52) yat punar } \\
\text { anumānaṃ } \\
\text { pratyakșāgamavi- } \\
\text { ruddhạ̣ } \\
\text { nyāyābhāsaḥ sa } \\
\text { (NM }{ }^{\mathrm{Va}} \text { I, p. 293, } \\
\text { 14-15) }\end{array}$ & iti & True & $\begin{array}{c}\text { Vātsyā- } \\
\text { yana }\end{array}$ \\
\hline
\end{tabular}


Table 9.3 continued

\begin{tabular}{|c|c|c|c|c|c|}
\hline Source & $\begin{array}{l}\text { Truth Pre-quote } \\
\text { val. }\end{array}$ & Re-use & $\begin{array}{l}\text { Post- } \\
\text { quote }\end{array}$ & $\begin{array}{l}\text { Truth } \\
\text { val. }\end{array}$ & $\begin{array}{l}\text { Point } \\
\text { of view }\end{array}$ \\
\hline $\begin{array}{l}\text { pramāṇena khalv } \\
\text { ayaṃ jñātārtham } \\
\text { upalabhya tam îpsati } \\
\text { vā jihāsati vā / } \\
\text { tasyepsājihāsāpra- } \\
\text { yuktasya samīhā } \\
\text { pravṛttir ity ucyate / } \\
\text { sāmarthyaṃ punar } \\
\text { asyāḥ phalenābhisam- } \\
\text { bandhah / (NBh ad } \\
\text { 1.1.1, p. 1,7-9) }\end{array}$ & True & $\begin{array}{l}\text { (53) pramāṇena khalv } \\
\text { ayạ̣ jñātārtham } \\
\text { upalabhya tam } \\
\text { īpsati vā jihāsati vā / } \\
\text { tasyepsājihāsā- } \\
\text { prayuktasya samīhā } \\
\text { pravṛttir ucyate / } \\
\text { sāmarthyạ̣ } \\
\text { punar asyāḥ } \\
\text { phalenābhisam- } \\
\text { bandhạ̣ / (NM }{ }^{\mathrm{Va}} \mathrm{II}, \\
\text { p. } 135,12-14)\end{array}$ & $\begin{array}{l}\text { iti ca } \\
\text { bruvāṇo } \\
\text { bhāṣya- } \\
\text { kāraḥ } \\
\text { [...] }\end{array}$ & True & $\begin{array}{c}\text { Vātsyā- } \\
\text { yana }\end{array}$ \\
\hline $\begin{array}{l}\text { nigrahasthānebhyah } \\
\text { pṛthag uddișțā } \\
\text { hetvābhāsā vāde } \\
\text { codanīyā } \\
\text { bhavișyantīti / (NBh } \\
\text { ad } 1.1 .1, \text { p. } 5,13)\end{array}$ & True & $\begin{array}{l}\text { (54) nigrahasthā- } \\
\text { nebhyạ̣ prethag } \\
\text { upadiștā hetvābhāsā } \\
\text { vāde codanīyā } \\
\text { bhavișyanti (NM } \\
\text { II, p. } 597,19-20)\end{array}$ & $\begin{array}{l}\text { iti bhāṣya- } \\
\text { kāra } \\
\text { vacanāt }\end{array}$ & True & $\begin{array}{c}\text { Vātsyā- } \\
\text { yana }\end{array}$ \\
\hline
\end{tabular}

\section{Re-use from Nyāya Sources}

In Tables 9.1-3 there is a small sample of re-uses from the NS and the NBh, as a term of comparison with the above-listed sources from other traditions. In Table 9.1, three quotations of the NS are shown, as an example of the many occurring in the NM. In Table 9.2, there are some re-uses from the NBh without an explicit mention of the NBh author. Finally, in Table 9.3, a few NBh re-uses with an explicit attribution are listed.

\section{Conclusions}

In Tables 10.1, 10.2 and 10.3 some characteristics of all the above re-uses are summarized for a better appreciation of specific patterns. The sequential number is shown in bold typeface when the re-use is a quotation. The context shows how re-uses constitute the back-bone of the whole argumentation in favor and against the sphota. It would be possible, indeed, to make sense of the main structure of the sphota section just by following the concatenation of arguments present in the quotations. The sequence of the arguments, however, differs from that found in previous sources, so Jayanta's claim of his role as a re-arranger seems corroborated by this survey.

In the re-uses surveyed here there are always three subjects involved: besides Jayanta himself (the Nyāya exponent), in fact, a dialog is staged between a symbolic re-user and the utterer of a re-used source, in the present case alternatively the Vaiyākaraṇa or the Mīmāmsaka. The symbolic re-user is in some cases explicitly 
Table 10.1 Sphoța defense

\begin{tabular}{|c|c|c|c|c|c|c|}
\hline & $\begin{array}{l}\text { Author of } \\
\text { source }\end{array}$ & $\begin{array}{l}\text { Context of re-used } \\
\text { passage }\end{array}$ & $\begin{array}{l}\text { Symbolic } \\
\text { re-user of } \\
\text { text }\end{array}$ & $\begin{array}{l}\text { Epist. val.: } \\
\text { author } \\
\text { of source }\end{array}$ & $\begin{array}{l}\text { Epist. } \\
\text { val.: } \\
\text { symb. } \\
\text { re-user }\end{array}$ & $\begin{array}{l}\text { Epist. } \\
\text { val.: } \\
\text { Jayanta }\end{array}$ \\
\hline \multicolumn{7}{|c|}{ Objections (Mīmāṃsaka) and Counter-objections (Vaiyākarạ̣a) } \\
\hline (1) & Kumārila & $\begin{array}{l}\text { Rejection of } \\
\text { simultaneity of } \\
\text { phonemes }\end{array}$ & Vyā. & True & True & True \\
\hline (2) & Kumārila & $\begin{array}{l}\text { Rejection of } \\
\text { simultaneity of } \\
\text { phonemes }\end{array}$ & Vyā. & True & True & True \\
\hline (3) & $\begin{array}{l}\text { Kumārila, } \\
\text { Uṃveka }\end{array}$ & $\begin{array}{l}\text { Necessity of sequence } \\
\text { of phonemes }\end{array}$ & Vyā. & True & True & True \\
\hline (4) & Śabara & $\begin{array}{l}\text { Process of } \\
\text { signification of } \\
\text { phonemes }\end{array}$ & $\begin{array}{l}\text { yad ucyate } \\
\text { (Śabara, } \\
\text { Mīm.) }\end{array}$ & True & False & $?$ \\
\hline$(5)$ & Kumārila & $\begin{array}{l}\text { Variegated or } \\
\text { cumulative sonic } \\
\text { image }\end{array}$ & Vyā. & True & False & $?$ \\
\hline (6) & Umveka & $\begin{array}{l}\text { Phonemes are } \\
\text { necessary to acquire } \\
\text { language } \\
\text { competence }\end{array}$ & Vyā. & True & False & True \\
\hline (7) & Kumārila & $\begin{array}{l}\text { Phonemes are } \\
\text { necessary to acquire } \\
\text { language } \\
\text { competence }\end{array}$ & $\begin{array}{l}\text { tad uktam } \\
\text { (Kumārila, } \\
\text { Mīm.) }\end{array}$ & True & False & True \\
\hline (8) & Śabara & $\begin{array}{l}\text { Common usage of } \\
\text { language supports } \\
\text { the sphota }\end{array}$ & Vyā. & False & True & False \\
\hline (9) & Śabara & $\begin{array}{l}\text { Phonemes are audible, } \\
\text { thus they are śabda }\end{array}$ & Vyā. & True & False & True \\
\hline (10) & Śabara & $\begin{array}{l}\dot{s} a b d a \text { is the cause of } \\
\text { knowledge of the } \\
\text { artha, i.e. the sphota }\end{array}$ & Vyā. & False & True & False \\
\hline (11) & Umveka & $\begin{array}{l}\dot{s} a b d a \text { is the cause of } \\
\text { knowledge of the } \\
\text { artha, i.e. the sphota }\end{array}$ & Vyā. & False & True & False \\
\hline (12) & Śabara & $\begin{array}{l}\text { The phonemes as } \\
\text { signifiers }\end{array}$ & Vyā. & True & False & True \\
\hline (13) & Kumārila & $\begin{array}{l}\text { The theory of } \\
\text { phonemes is more } \\
\text { economical }\end{array}$ & $\begin{array}{l}\text { bhatța } \\
\text { (Mīm.) }\end{array}$ & True & False & True \\
\hline (14) & Śabara & $\begin{array}{l}\text { The theory of } \\
\text { phonemes is more } \\
\text { economical }\end{array}$ & $\begin{array}{l}\text { bhāṣyakṛt } \\
\text { (Mīm.) }\end{array}$ & True & False & True \\
\hline
\end{tabular}


Table 10.1 continued

$\begin{array}{llllll}\begin{array}{l}\text { Author of } \\ \text { source }\end{array} & \begin{array}{l}\text { Context of re-used } \\ \text { passage }\end{array} & \begin{array}{l}\text { Symbolic } \\ \text { re-user of } \\ \text { text }\end{array} & \begin{array}{l}\text { Epist. val.: } \\ \text { author }\end{array} & \begin{array}{l}\text { Epist. } \\ \text { of source }\end{array} & \begin{array}{l}\text { Epist.: } \\ \text { symb. } \\ \end{array} \\ & & & \text { re-user } & \text { Jayanta }\end{array}$

Verdict (Vaiyākarạ̣a)

(15) Bhartrhari

The sphota is manifested through articulate sound

(16) Bhartṛhari

(17) Bhartṛhari

(18) Bhartrhhari

(19) Bhartrhhari

(20) Bhartrhhari

(21) Bhartrhari

(22) Bhartṛhari

(23) Bhartrihari

(24) Bhartrhari

(25) Bhartrhari

(26) Bhartṛhari

(27) Bhartṛhari
Phonemes and words are fictional

The sentence is not a whole made of parts

Phonemes have no independent meaning

Words are fictional abstractions

Words are fictional abstractions

\section{Divisions of} śabdabrahman as tools

\section{Divisions of} śabdabrahman as tools

\section{Divisions of śabdabrahman as tools}

The three-fold śabda

The three-fold śabda

The three-fold śabda

The three-fold śabda abstractions

\section{apare}

(Vyā.)

Vyā.

Vyā.

Vyā.

Vyā.

tad uktam

(Bhartrihari,

Vyā.)

Vyā.

Vyā.

yathoktam

(Bhartrhari, Vyā.)

Vyā.

tad uktam

(Bhartrhhari, Vyā.)

tad uktam (Bhartṛhari)

tad uktam

(Bhartṛhari)
True

True

True

False

True

True

False

True

True

False

True

True

False

True

True

False

True

True

False

True

True

False

True

True

False

True

True

False

True

True

False

True

True

False

True

True

False

mentioned, and in others clearly identifiable in the flow of the argument, according to his role in the debate either as proponent (pakșin) or opponent (pratipakșin).

Although the Mīmāmsaka role in the staged debate is that of presenting a second antithesis (uttarapakșa) and not a final verdict (siddhānta) one cannot fail to notice how Jayanta's views are very close to the Mīmāmsaka's, so much so that in the present list of re-uses, insofar as the truth value of the statements, Jayanta almost invariably agrees with the Mīmāmsaka. In these conclusive tables, the truth values seen from Jayanta's viewpoint are in bold face, together with the truth values of those who agree with him. 
Table 10.2 Sphoța refutation

\begin{tabular}{|c|c|c|c|c|c|c|}
\hline & $\begin{array}{l}\text { Author of } \\
\text { re-used text }\end{array}$ & $\begin{array}{l}\text { Context of } \\
\text { re-used passage }\end{array}$ & $\begin{array}{l}\text { Symbolic re-user } \\
\text { of text }\end{array}$ & $\begin{array}{l}\text { Epist. val. } \\
\text { according } \\
\text { to author } \\
\text { of source }\end{array}$ & $\begin{array}{l}\text { Epist. val. } \\
\text { according } \\
\text { to } \\
\text { symbolic } \\
\text { re-user }\end{array}$ & $\begin{array}{l}\text { Epist. } \\
\text { val. } \\
\text { according } \\
\text { to Jayanta }\end{array}$ \\
\hline \multicolumn{7}{|c|}{ Counter-verdict (Mīmāṃsaka) } \\
\hline (28) & Kumārila & $\begin{array}{l}\text { Phonemes in } \\
\text { sequence produce a } \\
\text { cumulative effect }\end{array}$ & Mīm. & True & True & True \\
\hline$(29)$ & Uṃveka & $\begin{array}{l}\text { Phonemes in } \\
\text { sequence produce a } \\
\text { cumulative effect }\end{array}$ & Mīm. & True & True & True \\
\hline (30) & Umuveka & $\begin{array}{l}\text { Phonemes in } \\
\text { sequence produce a } \\
\text { cumulative effect }\end{array}$ & Mīm. & True & True & True \\
\hline (31) & Śabara & $\begin{array}{l}\text { The last phoneme } \\
\text { triggers knowledge } \\
\text { of the artha }\end{array}$ & $\begin{array}{l}\text { tatrabhāvān } \\
\text { mīmāṃsā- } \\
\text { bhāṣyakṛt (Mīm.) }\end{array}$ & True & True & True \\
\hline$(32)$ & Uṃveka & $\begin{array}{l}\text { Dispositions are } \\
\text { qualities of the self }\end{array}$ & Mīm. & True & True & True \\
\hline (33) & Śabara & $\begin{array}{l}\text { Perception is the } \\
\text { main instrument } \\
\text { of knowledge }\end{array}$ & Mīm. & True & True & True \\
\hline (34) & Umveka & $\begin{array}{l}\text { Perceptions produce } \\
\text { dispositions, which } \\
\text { produce memory }\end{array}$ & $\begin{array}{l}\text { tathā cāhuh } \\
\text { (Mīm.) }\end{array}$ & True & True & True \\
\hline (35) & Śabara & $\begin{array}{l}\text { The theory of } \\
\text { phonemes is more } \\
\text { economical }\end{array}$ & $\begin{array}{l}\text { sugṛhītanāma- } \\
\text { bhāṣyakāra, } \\
\text { Mīm. }\end{array}$ & True & True & True \\
\hline (36) & Kumārila & $\begin{array}{l}\text { The theory of the } \\
\text { sphota is anti- } \\
\text { economical }\end{array}$ & $\begin{array}{l}\text { tad uktam } \\
\text { (Kumārila, } \\
\text { Mīm.) }\end{array}$ & True & True & True \\
\hline (37) & Kumārila & $\begin{array}{l}\text { A gradual } \\
\text { manifestation of the } \\
\text { sphota is impossible }\end{array}$ & $\begin{array}{l}\text { yathoktam } \\
\text { (Kumārila) }\end{array}$ & True & True & True \\
\hline (38) & Kumārila & $\begin{array}{l}\text { The sequence is a } \\
\text { property of } \\
\text { phonemes, not an } \\
\text { additional } \\
\text { postulation like the } \\
\text { sphota }\end{array}$ & $\begin{array}{l}\text { tatra coktam } \\
\text { (Kumārila, } \\
\text { Mīm.) }\end{array}$ & True & True & True \\
\hline (39) & Kumārila & $\begin{array}{c}\text { The sphota does not } \\
\text { qualify as śabda }\end{array}$ & $\begin{array}{l}\text { tad uktam } \\
\text { (Kumārila, Mīm.) }\end{array}$ & True & True & True \\
\hline (40) & Pakṣilasvāmin & $\begin{array}{c}\text { The sphota does not } \\
\text { qualify as śabda }\end{array}$ & bhāșyakṛt (Mīm.) & True & True & True \\
\hline (41) & Kumārila & $\begin{array}{l}\text { The smallest śabda } \\
\text { unity is the } \\
\text { phoneme }\end{array}$ & Mīm. & True & True & True \\
\hline (42) & Kumārila & $\begin{array}{l}\text { The smallest } s a b d a \\
\text { unity is the phoneme }\end{array}$ & $\begin{array}{l}\text { sūktam hy etat } \\
\text { (Kumārila, Mīm.) }\end{array}$ & True & True & True \\
\hline
\end{tabular}


Table 10.3 Nyāya sources

\begin{tabular}{|c|c|c|c|c|c|c|}
\hline & $\begin{array}{l}\text { Author of } \\
\text { re-used text }\end{array}$ & $\begin{array}{l}\text { Context of re-used } \\
\text { passage }\end{array}$ & $\begin{array}{l}\text { Symbolic re-user } \\
\text { of text }\end{array}$ & $\begin{array}{l}\text { Epist. val. } \\
\text { according } \\
\text { to author } \\
\text { of source }\end{array}$ & $\begin{array}{l}\text { Epist. val. } \\
\text { according } \\
\text { to symbolic } \\
\text { re-user }\end{array}$ & $\begin{array}{l}\text { Epist. val. } \\
\text { according } \\
\text { to Jayanta }\end{array}$ \\
\hline \multicolumn{7}{|c|}{ Re-uses from the NS } \\
\hline (43) & Akșapāda & $\begin{array}{l}\text { The instruments } \\
\text { of knowledge }\end{array}$ & $\begin{array}{l}\text { tad āha } \\
\text { sūtrakārah (Nyā.) }\end{array}$ & True & True & True \\
\hline (44) & Akșapāda & $\begin{array}{l}\text { Knowledge of the } \\
\text { self leads to the } \\
\text { summum bonum }\end{array}$ & $\begin{array}{l}\text { akșapādas tāvad } \\
\text { evam } \\
\text { upadisțavān } \\
\text { (Nyā.) }\end{array}$ & True & True & True \\
\hline (45) & Akșapāda & $\begin{array}{l}\text { The purpose of } \\
\text { jalpa and } \\
\text { vitand } \bar{a}\end{array}$ & $\begin{array}{l}\text { samāhitam } \\
\text { etad bhagavatā } \\
\text { sūtrakāreṇa } \\
\text { (Nyā.) }\end{array}$ & True & True & True \\
\hline \multicolumn{7}{|c|}{ Uncredited re-uses from the NBh } \\
\hline (46) & Vātsyāyana & $\begin{array}{l}\text { The syntax of NS } \\
1.1 .1\end{array}$ & Nyā. & True & True & True \\
\hline (47) & Vātsyāyana & $\begin{array}{l}\text { The relation of } \\
\text { pramāna and } \\
\text { prameya with } \\
\text { the other } \\
\text { padārthas }\end{array}$ & Nyā. & True & True & True \\
\hline (48) & Vātsyāyana & $\begin{array}{l}\text { Inference is used } \\
\text { to solve doubts }\end{array}$ & Nyā. & True & True & True \\
\hline (49) & Vātsyāyana & $\begin{array}{l}\text { The three } \\
\text { pravrttis: } \\
\text { uddeśa, laksana } \\
\text { and parīkșa }\end{array}$ & Nyā. & True & True & True \\
\hline \multicolumn{7}{|c|}{ Credited re-uses from the NBh } \\
\hline (50) & Vātsyāyana & $\begin{array}{l}\text { Ānvīkssikī is the } \\
\text { supreme science }\end{array}$ & $\begin{array}{l}\text { āha ca } \\
\text { bhāşsyakāraḥ } \\
\text { (Nyā.) }\end{array}$ & True & True & True \\
\hline (51) & Vātsyāyana & $\begin{array}{l}\text { The convergence } \\
\text { of instruments of } \\
\text { knowledge in a } \\
\text { single object }\end{array}$ & $\begin{array}{l}\text { tad udāhāraṇam tu } \\
\text { bhāșyakārạ̣ } \\
\text { pradarśitavān } \\
\text { (Nyā.) }\end{array}$ & True & True & True \\
\hline (52) & Vātsyāyana & Pseudo-inferences & $\begin{array}{c}\text { bhāșyakāreṇa } \\
\text { uktam (Nyā.) }\end{array}$ & True & True & True \\
\hline (53) & Vātsyāyana & $\begin{array}{l}\text { Definition of } \\
\text { pravrtti }\end{array}$ & $\begin{array}{l}\text { iti ca bruvāna } \\
\text { bhāsyakāāaḥ } \\
\text { (Nyā.) }\end{array}$ & True & True & True \\
\hline (54) & Vātsyāyana & $\begin{array}{l}\text { The scope of } \\
\text { pseudo-logical } \\
\text { reasons }\end{array}$ & $\begin{array}{l}\text { iti bhāssyakāarava- } \\
\text { canāt (Nyā.) }\end{array}$ & True & True & True \\
\hline
\end{tabular}


Throughout the NM, when not explicitly credited to the author, quotations are almost invariably introduced by tad uktam, or, more rarely, yathoktam. The overwhelming percentage of quotations thus introduced is in verse or sütra form. This tad uktam pre-quote expression can be considered Jayanta's marker for a precise quotation, so much so that it may be used as a valuable clue to identify quotations from undetermined or lost works. Also, it is a signal that the specific tradition derived from the context, in the above cases Vyākarana and Mīmāmsāa, is symbolized in the quotation. Unlike Śabara and Kumārila, Bhartrihari is never explicitly credited. Since Jayanta's views are certainly closer to the Mīmāmsakas's, such explicit credits could by themselves be not only tokens of respect, but also of the trustworthiness of the source.

The almost invariable concomitance of the tad uktam formula with quoted verses and aphorisms may have several reasons. It is possible that verses were more suited for quotation purposes, for mnemonic reasons, and that therefore Jayanta thinks more appropriate to introduce them with an explicit "so it was said". It is also possible that verses and aphorisms, since they were more easily memorized and thus faithfully transmitted, enjoyed a special status as śabdapramāṇa in Jayanta's perspective.

It is remarkable how differently re-uses from Nyāya sources are treated. First of all, in these cases the tad uktam pre-quote is not systematically present anymore. There is a substantial amount of uncredited quotations from the NBh, which is all in prose, except for rare passages (see Table 10.3). Perhaps these passages were so well known to Jayanta and his audience to make irrelevant the necessity of credits, or perhaps in Jayanta's understanding only versified passages were worthy of credits, but in some cases they could also be unconscious re-uses creeping in the NM. ${ }^{14}$ In the context of versification, I found (48) particularly interesting, where a prose passage of the NBh is integrated and completed in metrical form by Jayanta.

In relation to re-use in Nyāya literature, in any case, it seems that the impact of the oral tradition, and thus of massive portions of works committed to memory, must be taken into account.

Open Access This article is distributed under the terms of the Creative Commons Attribution License which permits any use, distribution, and reproduction in any medium, provided the original author(s) and the source are credited.

\section{References}

\section{Abbreviations and References to Primary Literature}

Bṛh Prabhākara Miśra (1929). Bṛhatī by Prabhākara Miśra with the commentary Rjuvimalā of Śālikanātha Miśra. Ed. by A. Chinnaswami Sastri. Chowkhambā Sanskrit Series 391. Benares: Vidya Vilas Press.

C Ms. 2606, Malayalam Department of the University of Calicut, Thenjipalam (Malappuram District). Undated; foll. 188; cm. 5 × 48 ca.; palm-leaf; Malayālam. Contains the complete NM 16 and about one third of NM 7. In the original foliation, the first leaf is foliated as śrī, and is followed by foll. 1-187 in letter numerals.

\footnotetext{
$\overline{14}$ For a parallel case in Mīmāṃsā, see Freschi's contribution in this volume.
} 
GBh Nagin J. Shah, ed. (1972). Cakradhara's Nyāyamañjarī-granthibhañga. Lalbhai Dalpatbhai series, 35. Ahmedabad: L.D. Institute of Indology.

NBh Anantalal Thakur, ed. (1997b). Gautamīyanyāyadarśana with Bhāssya of Vātsyāyana. Nyāyacaturgranthika 1 . For the first chapter, it is the revised edition of the same author's edition of the Nyāyacaturgranthika, Adhyāya 1. Mithila Institute Series Ancient Text 20. Darbhanga 1967. New Delhi: Indian Council of Philosophical Research.

$\mathrm{NM}^{\mathrm{Ga}}$ Mahamahopadhyaya Gangadhara Shastri Tailanga, ed. (1895). The Nyāyamañjarì of Jayanta Bhatta. Vizianagram Sanskrit Series 8. Benares: E.J. Lazarus and Co.

$\mathrm{NM}^{\mathrm{Va}}$ K.S. Varadācārya, ed. (1969-1983). Nyāyamañjarī: with Tịppaṇī Nyāyasaurabha. Two volumes. Mysore: Oriental Research Institute.

NS see NBh.

P Ms. 390/1875-76, Bhandarkar Oriental Research Institute, Pune. Śaka 1394 [CE 1472]; foll. 432; mm. $130 \times 130$; birch-bark, bound; Śāradā. The manuscript is presently constituted of 432 leaves (435 according to Cat. Report 1875, p. XXV). The original foliation runs up to NM 3 and restarts from NM 4: 3-149 (= NM 1-3) + 1-270 (= NM 4-12) + 282-286 (an unidentified work) + 7 (parts of Raghuvamśa 15.11-78). Except for occasional missing leaves, the NM is complete. The first two folios are lost.

PSṬ Ernst Steinkellner, Helmut Krasser, and Horst Lasic, eds. (2005). Jinendrabuddhi's Viśalämalavatī Pramānasamuccayațīkā. Beijing-Vienna: Austrian Academy of Sciences Press.

ŚBh Kashinath Vasudev Abhyankar and Ganesh Shastri Ambadas Joshi, eds. (1970-1974). Mīmāmsāādarśana. Ānandāśramasamskrtagranthāvāli 97. Vol. 1: MS 1.1, with Śābarabhāṣya and Prabhābhidhā commentary by Vaidyanath Shastri. Vol. 2: MS 1.2-2.1, with Śābarabhāṣya and Tantravārttika. Vol. 3: MS 2.2-2.4, with Śābarabhāṣya and Tantravārttika. Vol. 4: MS 3.13.8, with Śābarabhāṣya and Tantravārttika. Vol. 5: MS 4.1-7.4, with Śābarabhāṣya and Ṭupțīkā. Vol. 6: MS 8.1-10.8, with Śābarabhāṣya and Țupțīkā. Vol. 7: MS 11.1-12.4, with Śābarabhāṣya and Țupțīā. Or. ed. 1930-1933. Pune: Anandashrama.

ŚV $V^{\text {Dvāa }}$ Śāstrī Dvārikādāsa, ed. (1978). Ślokavārttika of Śrī Kumārila Bhațta with the Commentary Nyāyaratnākara of Śrī Pārthasārathi Miśra. Prāchyabhārati Series 10. Varanasi.

$S^{\mathrm{S}} \mathrm{V}^{\mathrm{Ra}}$ S.K. Ramanatha Sastri, ed. (1971). Ślokavārtikavyākhyā Tātparyațīkā of Umveka Bhața. Revised by K. Kunjunni Raja and R. Thangaswamy. Or. Ed. 1940. University of Madras, p. 672.

ŚVTṬ see ŚV $\mathrm{R}^{\mathrm{R}}$.

SphS Madeleine Biardeau, ed. (1958). La demonstration du sphota par Mandana Miśra. Introduction, traduction et commentaire. Pondichéry: Institut français d'Indologie.

TB V.A. Ramaswami Sastri, ed. (1936). Tattvabindu by Vācaspatimiśra with Tattvavibhāvanā by Rsiputra Parameśvara. Madras: Annamalai University.

VP Wilhelm Rau, ed. (1977). Bharțharis Vākyapadīya. Deutsche Morgenländische Gesellschaft, Band XLII, 4. Wiesbaden: Franz Steiner.

\section{Secondary Sources}

Bhattacharyya, S. (1994). Epistemology of testimony and authority: Some Indian themes and theories. In B. K. Matilal \& A. Chakrabarti (Eds.), Knowing from words. Dordrecht: Kluwer.

Dezsô, C. (Ed.). (2005). Much ado about religion. Sanskrit text and translation of Bhațta Jayanta's Agamadambara. The Clay Sanskrit Library. New York: New York University Press.

Eco, U. (1996). Semiotica e Filosofia del Linguaggio. Or. ed. 1984. Torino: Einaudi.

Graheli, A. (2008). In praise of repetition. IIAS Newsletter, 48, 24.

Graheli, A. (2012a). A preliminary list and description of the Nyāyamañjarī manuscripts. Journal of Indian Philosophy, 40, 317-337.

Graheli, A. (2012b). The choice of the best reading in Jayanta Bhațta's Nyāyamañjarī. In E. Freschi, et al. (Eds.), The study of Asia between antiquity and modernity. Rivista degli Studi Orientali, 84, 107-122.

Graheli, A. (forthcoming). The force of tātparya: From Bhațta Jayanta to Abhinavagupta. In E. Franco \& I. Ratié (Eds.), Around Abhinavagupta: Aspects of the Intellectual History of Kashmir from the 9th to the 11th centuries. 
Jack, J. (1994). The role of comprehension. In B. K. Matilal \& A. Chakrabarti (Eds.), Knowing from words. Dordrecht: Kluwer.

Kataoka, K. (2007). Was Bhaț̣a Jayanta a Paippalādin? In A. Griffiths \& A. Schmiedchen (Eds.), The Atharvaveda and its Paippalādaśākhā. Geisteskultur Indiens: Texte und Studien 11. Aachen: Shaker, pp. 319-333.

Kunjunni Raja, K. (1963). Indian theories of meaning. Madras: Adyar Library and Research Centre.

Matilal, B. K. \& Sen, P. K. (1988). The context principle and some Indian controversies over meaning. Mind, 97(385), 73-97.

Matilal, B. K., \& Chakrabarti, A. (Eds.). (1994). Knowing from words. Western and Indian philosophical analysis of understanding and testimony. Dordrecht: Kluwer.

Mohanty, J. N. (1994). Is there an irreducible mode of word-generated knowledge? In B. K. Matilal \& A. Chakrabarti (Eds.), Knowing from words. Dordrecht: Kluwer.

Moravcsik, J. M., \& Poovanalingam, M. (1975). Some results on the function and quality of citations. Social Studies of Science, 5(1), 86-92.

Potter, K. H. (Ed.). (1995). The tradition of Nyāya-Vaiśeșika up to Gañgeśa. In Encyclopedia of Indian philosophies (Vol. 2, Or. ed. 1977). New Delhi: Motilal Banarsidass.

Preisendanz, K. (2009). Logic, debate and epistemology in ancient Indian medical science. An investigation into the history and historiography of Indian philosophy. Indian Journal of History of Science, 44(2), 261-312.

Saksena, S. K. (1951). Authority in Indian philosophy. Philosophy East and West, 1(3), 38-49.

Slaje, W. (1986). Untersuchungen zur Chronologie einiger Nyāya-Philosophen. Studien zur Indologie und Iranistik, 11-12, 245-278.

Slaje, W. (2012). Wann, Wo und Weshalb schrieb Bhața Jayanta seine "Blütenrispe am Baum des Nyāya"? In R. Steiner (Ed.), Highland philology (pp. 121-142). Halle (Saale): Universitätsverlag Halle-Wittenberg.

Small, H. G. (1978). Cited documents as concept symbols. Social Studies of Science, 8(3), 327-340. 